\title{
Institutional Strategies in Emerging Markets
}

\section{Citation}

Marquis, Christopher, and Mia Raynard. "Institutional Strategies in Emerging Markets." Harvard Business School Working Paper, No. 15-013, September 2014.

\section{Permanent link}

http://nrs.harvard.edu/urn-3:HUL.InstRepos:13350449

\section{Terms of Use}

This article was downloaded from Harvard University's DASH repository, and is made available under the terms and conditions applicable to Open Access Policy Articles, as set forth at http:// nrs.harvard.edu/urn-3:HUL.InstRepos:dash.current.terms-of-use\#OAP

\section{Share Your Story}

The Harvard community has made this article openly available.

Please share how this access benefits you. Submit a story.

Accessibility 
H A R VAR D

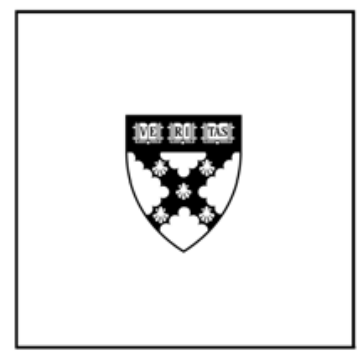

\title{
Institutional Strategies in Emerging Markets
}

\author{
Chris Marquis \\ Mia Raynard
}

\section{Working Paper}

15-013

September 01, 2014

Copyright (C) 2014 by Chris Marquis and Mia Raynard

Working papers are in draft form. This working paper is distributed for purposes of comment and discussion only. It may not be reproduced without permission of the copyright holder. Copies of working papers are available from the author. 


\section{INSTITUTIONAL STRATEGIES IN EMERGING MARKETS*}

\author{
Chris Marquis \\ Cornell University \\ cmarquis@cornell.edu
}

\author{
Mia Raynard \\ University of Alberta \\ mia2@ualberta.ca
}

\section{Prepared for: \\ Academy of Management Annals \\ Volume 9 (2015)}

September 1, 2014

* We thank Olga Hawn, Shon Hiatt, Nan Jia, Rajiv Kozhikode, Michael Lounsbury, Yadong Luo, Johanna Mair, Ilya Okhmatovskiy, Andras Tilcsik, and Danqinq Wang for their comments on prior versions of this paper. 


\title{
INSTITUTIONAL STRATEGIES IN EMERGING MARKETS
}

\begin{abstract}
We review and integrate a wide range of literature that has examined the strategies by which organizations navigate institutionally diverse settings and capture rents outside of the marketplace. We synthesize this body of research under the umbrella term institutional strategies, which we define as the comprehensive set of plans and actions directed at strategically leveraging and shaping the socio-political and cultural institutions within an organization's external environment. Our review of institutional strategies is focused on emerging market contexts, settings that are characterized by weak capital market and regulatory infrastructures and fast-paced turbulent change. Under such challenging conditions, strategies aimed at shaping the institutional environment may be especially critical to an organization's performance and long-term survival. Our review reveals that organizations engage in three specific and identifiable sets of institutional strategies, which we term: relational, infrastructurebuilding, and socio-cultural bridging. We conclude by highlighting fruitful avenues for crossdisciplinary dialogue in the hope of promoting future research on emerging markets and defining the next frontier of institutional theory in organizational analysis.
\end{abstract}




\section{INSTITUTIONAL STRATEGIES IN EMERGING MARKETS}

In an increasingly complex and integrated global economy, a significant challenge for organizations is navigating institutionally diverse contexts - each posing a different set of opportunities and challenges. Scholars over the past decades have articulated the multifaceted influence of institutions on organizations and competition, with some traditions foregrounding

formal and legal aspects (Hall, 1986; North, 1990; Williamson, 2000) while others focusing more on informal and socio-cultural aspects (Meyer \& Rowan, 1977; DiMaggio \& Powell, 1983). North (1991: 87) defined institutions as "humanly devised constraints that structure political, economic and social interaction." For Scott (2014: 56), institutions are the "regulative, normative, and cultural-cognitive elements that, together with associated activities and resources, provide stability and meaning to social life." While extensive research has focused on the effects of institutional variation on organizations (Peng et al., 2008; Greenwood et al., 2011), less attention has been paid to examining the ways in which organizations purposefully and strategically shape their institutional environment. Yet, as recent research has begun documenting, the effective management of socio-political and cultural institutions is no less important to organizational survival than marketplace success (Hillman \& Hitt, 1999; Lounsbury \& Glynn , 2001; Marquis \& Qian, 2014; Seelos \& Mair, 2007).

In this paper, we review and integrate recent literatures that have documented a variety of strategies by which organizations attend to institutionally diverse settings and capture rents outside of the marketplace, including strategies that seek to influence the public policy arena and benefit from the non-market environment (Henisz \& Zelner, 2003; Hillman, Keim, \& Schuler, 2004; Kozhikode \& Li, 2012), to transform institutions (Campbell, 1998; Hillman \& Hitt, 1999; Lawrence, 1999), and to engage with key stakeholder groups (Freeman, 1984; Galaskiewicz, 
1985; Mitchell, Agle, \& Wood, 1997). While these efforts have shed light on the complexity of organizational behaviors, our understanding of the diversity and contextual relevance of different types of institutional strategies remains balkanized and selective.

We focus our review of institutional strategies on emerging market economies - broadly defined as countries undergoing fast-paced turbulent change as a result of economic liberalization, rapid industrialization, and increased integration into the global economy. In these contexts, the society and economy are undergoing a process of coevolution, and the onus is often on organizations to pursue and promote not only economic but also social development (Hoskisson, Eden, Lau \& Wright, 2000; Luo, 2006; Mair, Marti, \& Ventresca, 2012). In the last decade, emerging economies have assumed an increasingly prominent position in the global economy, such that they are projected to account for more than half of world GDP on the basis of purchasing power by the end of 2014 (see Figure 1). The rapid rise and development of emerging economies such as China, India, Brazil, Russia, Turkey, and Indonesia in the $21^{\text {st }}$ century has attracted tremendous interest from managers and investors, yet our theories have not kept pace (Davis \& Marquis, 2005). As Wright, Filtotchev, Hoskisson, and Peng (2005: 27) convincingly argue, research with a focus on emerging economies is both an opportunity and a necessity - as they are "fertile grounds not only for testing existing theories but also for developing new ones." Accordingly, we propose that research in emerging economies feature more prominently in organizational studies as we move forward.

[Insert Figure 1 about here]

While the specific context that we examine in the paper is emerging economies, our intention is to review and synthesize various streams of research; and in so doing, identify and map the complex array of institutional strategies that firms undertake - which can then be 
generalized to business organizations in other contexts as well. To date, strategies that can be considered part of firms' institutional strategizing have been variously referred to as non-market or political strategies (De Figueiredo \& Tiller, 2001; Hillman \& Hitt, 1999; Hillman et al., 2004; Baron, 1995), collective action (King \& Pearce, 2010; Schneiberg \& Lounsbury, 2008; Walker \& Rea, 2014), and stakeholder management (Freeman, 1984; Mitchell et al., 1997). Although these literatures are not traditionally considered under the institutional theory ambit, a common feature is that they address how organizations strategically manage their broader external environments; and, as such, provide important insights for theorizing about institutional processes. Conceptualizing these strategies as 'institutional' provides an opportunity to synthesize these rich, yet disparate streams of research - thus, offering a more accurate identification of the overarching conceptual domain.

We define the term institutional strategy as the comprehensive set of plans and actions directed at leveraging and shaping the socio-political and cultural institutions within an organization's external environment. Our review of the literature reveals that organizations engage in three specific and identifiable sets of institutional strategies, which we term: relational, infrastructure-building, and socio-cultural bridging. In unpacking the concept of institutional strategies in this way, we aim to develop an integrative framework that outlines a more interactive and reciprocal view of institutional processes - one that highlights the agentic and intent-driven nature of organizational responses to institutional pressures, and the importance of institutional perspectives in firms' strategic action in the globalizing economy. We argue that such a perspective is an important new frontier of institutional research in organizational studies. Thus, our review is centered on highlighting important areas for cross-disciplinary dialogue, and 
guiding future scholarship in exploring how organizations navigate the complexities of their institutional environments.

\section{INSTITUTIONAL STRATEGIES AS THE NEW FRONTIER OF INSTITUTIONAL RESEARCH IN ORGANIZATIONAL STUDIES}

Beginning in the 1970s, scholars from various disciplines including economics, political science and sociology began focusing on how institutions - or the formal and informal "rules of the game" - affected organizational and economic activity (North, 1990; Scott, 2001). In organizational studies, the research that built on this tradition tended to emphasize the capacity of institutions to control and constrain organizational behavior through external environmental factors (c.f. Greenwood, Oliver, Sahlin, \& Suddaby, 2008; Scott, 2014; Thornton, Ocasio, \& Lounsbury, 2012). For example, significant empirical work in this area focused on how cultural expectations, legitimacy, and isomorphic processes exerted pressures on the organization to conform to "legitimate practice" in a given institutional field (e.g. Fligstein, 1985; Galaskiewicz \& Wasserman, 1989; Davis, 1991). This early work in institutional theory was powerful in demonstrating the substantial isomorphic forces in organizational fields, which "impose restrictions by defining legal, moral, and cultural boundaries, distinguishing between acceptable and unacceptable behavior" (Scott, 2014: 58) - thus, addressing DiMaggio and Powell's original question of "why do organizations look so similar?"

Later streams of research within organizational studies shifted the focus from examining continuity and constraint in social structures to exploring how actors exercise agentic behavior and instigate change (c.f. Hirsch \& Lounsbury, 1997; Thornton et al., 2012). As Oliver (1991) pointed out, organizational responses to homogenizing institutional pressures can range from passive conformity to active resistance depending on the nature and context of the pressures. Yet 
beyond active resistance is the possibility that organizations may adopt a more proactive and agentive stance towards such pressures. North (2006:60), for example, notes that organizations may induce institutional change directly or indirectly by "altering the rules" through political bodies or social organizations; or, by "deliberately (and sometimes accidentally) altering the ... effectiveness of sanction and other means of informal constraint enforcement." Recent studies of institutional change within mature fields have also shown that organizations confronted with multiple, potentially conflicting, institutional pressures become aware of field-level 'contradictions' - which enable them to think reflexively about the limitations of existing arrangements (Battliana et. al. 2006; Friedland \& Alford, 1991; Greenwood \& Suddaby, 2006; Greenwood et al., 2011; Kraatz \& Block, 2008; Seo \& Creed, 2002). This reflexivity opens up the possibility for embedded actors to collectively mobilize in an effort to strategically shape the institutional context around them.

Research in other disciplines, including strategy and international business, have also embraced an institutional perspective - one that is rooted both in the sociological work mentioned above as well as economic traditions stemming from the work of Douglass North (1990; e.g. see La Porta, Lopez-de-Silanes, \& Shleifer, 1998). As Ingram and Silverman (2002: 20) noted, "institutions directly determine what arrows a firm has in its quiver as it struggles to formulate and implement strategy." With the changing competitive landscape confronting firms as globalization progresses, scholars have increasingly advocated taking an "institution-based" approach to investigate and understand how contextual factors affect competition, performance, and the development of sustainable competitive advantages (Ahuja \& Yayavaram, 2011; Peng et al., 2008; Oliver, 1997). While the above sets of research have examined the affects of institutional pressures and contexts on organizational action, there has been growing recognition 
that organizations think strategically about institutions - both about global contexts more generally, and about the need to adapt to the particularities of local contexts. The term institutional strategy was first considered by Lawrence (1999: 161), who identified two basic types: “(1) membership strategies that involve the definition of rules of membership and their meaning for an institutional community; and (2) standardization strategies that are concerned with the establishment of technical legal or market standards that define the "normal" processes involved in the production of some good or service." While we agree that these are important, they may only scratch the surface of what is possible and necessary in today's global environment.

Building on the widespread interest in institutional processes and their effects on organizations, we review a series of literatures that aim to explain how organizations are active in shaping their external environments. While these literatures derive from different legacies and antecedents, taking stock of this growing body of research is critical to our capacity to think comprehensively about the institutional conditions confronting organizations. We integrate these literatures under a common heading by adopting a broad definition of institutional strategies one that includes all plans and actions taken by organizations to strategically manage sociopolitical and cultural institutions, or leverage them to an organization's competitive advantage. Our main point is that organizations need to be proactive about diagnosing and shaping their external environments. Contrasting with earlier perspectives that viewed institutions as top-down pressures that shaped organizations (Scott, 2011), our perspective foregrounds the strategic interaction between organizations and their institutional environments. In doing so, our review aims to showcase institutional theory as the theory of action for the 21 st century. 
In the following section, we outline the critical features that differentiate emerging markets from developed markets, and draw attention to the importance of these differences on an organization's operations, strategic focus, and overall competitive landscape.

\section{WHY INSTITUTIONAL STRATEGIES ARE ESSENTIAL IN EMERGING MARKETS}

As key growth markets for firms, emerging markets have attracted increased scholarly attention $(\mathrm{Li}, 2001)$ - with emphasis being placed on examining the role of institutional factors in channeling organizational decisions and actions. This growing interest is clearly reflected in two recent special issues on strategic management in emerging markets. In Hoskisson et al.'s (2000) Academy of Management Journal special issue, the editors highlighted institutional theory as one of the key theories used in the special issue papers. Then, five years later, in a special issue of the Journal of Management Studies, Wright et al. (2005) noted that institutional theory "has indeed risen, as predicted by Hoskisson et al. (2000), to become a new dominant theory guiding strategy research on emerging economies."

As scholarship on emerging markets has developed over recent decades, researchers have pointed to a number of important differences among emerging economies. Most notable is the difference between traditional developing countries in Asia, Latin America, Africa, and the Middle East and transition economies in the former Soviet Union, Eastern Europe and East Asia (Hoskisson et al., 2000; Khanna \& Palepu, 2010; Wright et al., 2005). This latter group of countries is uniquely characterized by a shift from a centrally planned economy to a market economy - reflected in increased privatization, the changing role of government, and legal and institutional reforms. Other important differences between emerging markets include the level of industrial development, the extent of market liberalization, the degree of integration into the global economy, and the rate of economic development and growth. 
Despite these differences, emerging economies share a number of characteristics that not only differentiate them from the more traditionally studied developed markets, but also create a set of general challenges for navigating their business environments. Thus, for the purposes of our review, we focus more on the similarities across emerging markets in terms of economic, market and institutional conditions. We also highlight key sources of variation between emerging and developed market contexts - which we argue is an important first step in better understanding how organizations can strategically manage or alter aspects of their institutional environment to their competitive advantage. In the discussion we offer recommendations for future research that examines how the institutional strategies that we identify may vary across different emerging economies.

Economic and Market Conditions. A defining feature of emerging market economies is that they are "low-income, rapid-growth countries using economic liberalization as their primary engine of growth" (Hoskisson et. al, 2000: 249; see also Arnold \& Quelch, 1998). The importance of such markets to global corporations and investors is demonstrated by the proliferation of emerging market typologies, such as BRICS, CIVITS, EAGLES, ${ }^{1}$ and the development of lists of emerging economies by key market actors including the IMF, FTSE, MSCI, S\&P, Dow Jones and Russell. Table 1 provides a list of countries considered emerging economies across current categorizations - importantly, it shows general convergence on which countries are included.

[Insert Table 1 about here]

1 The BRICS are Brazil, Russia, India, China, and South Africa; CIVITS are Columbia, Indonesia, Vietnam, Egypt, Turkey, and South Africa; EAGLES are Brazil, China, India, Indonesia, South Korea, Mexico, Russia, Taiwan, and Turkey. 
Figure 2 plots the major countries of the world along the dimensions of economic growth rate and per capita GDP - key dimensions by which emerging economies are identified. As the figure shows, countries that are typically considered emerging economies are clustered in the middle of the graph, occupying a prime spot with respect to future growth prospects: relatively high recent GDP growth rates and moderate GDP per capita. These economies are often characterized by rapidly improving living standards, active consumer markets, and a burgeoning middle class population. Advanced economies, in contrast, are clustered on the bottom right side of the graph, reflecting a relatively low average GDP growth rate and high GDP per capita. These economies have typically reached a relatively mature state of industrial development and are characterized by a service-oriented market and minimal government intervention in the business sphere. As for developing economies, the average GDP growth rate varies considerably and the average GDP per capita is low - leading to a clustering of these countries on the left side of the graph. These developing countries tend to have high levels of poverty and unemployment, accompanied by low standards of living and short life expectancies.

[Insert Figure 2 about here]

In terms of economic and market conditions, emerging economies differ markedly from advanced economies in a number of systematic ways. Rapid economic development, industrialization, and modernization make emerging markets particularly attractive destinations for export, foreign direct investment, and the sourcing of production and manufacturing. Thus, there are critical differences in the business mix - with emerging economies having a higher proportion of manufacturing, labor-intensive industries, and large-scale heavy industrial sectors (Murrel \& Wang, 1993; Sit \& Liu, 2000). Such characteristics are in many ways the hallmark of their growth trajectories, as lower labor costs tend to drive growth in manufacturing and exports. 
This pattern, however, has been shown to shift over time as the emerging market grows and evolves. In particular, rising household incomes provide consumers with more opportunities for discretionary purchases, resulting in the emergence of a middle-class consumer sector - as was the case for Indonesia and the Philippines, which have now transitioned into strong domestic economies.

Capital markets also tend to be less developed in emerging economies than in advanced ones - thus, making financial exchanges more volatile, trading less liquid, and inflation particularly problematic. Moreover, key financial intermediaries such as accounting firms, financial analysts, and venture capitalists are typically either absent or only marginal present ( $\mathrm{Li}$ \& Atuahene-Gima, 2002; Peng \& Heath, 1996) - creating information asymmetries within the markets that can be exploited by firms. Not only does this increase the potential for opportunism because of the prohibitively high costs monitoring (Marquis \& Qian, 2014), but it also makes legal contracts difficult to enforce. Overall, the conditions imply a relatively higher degree of volatility in the market and rapidly changing risk profiles, as compared to their more developed counterparts.

Institutional Conditions. In addition to baseline economic differences, numerous political, legal, socio-cultural, and technological factors differentiate the business environment of emerging economies from that of developed economies. One critical factor is the strong influence of the government and the prevalence of state-owned firms (Douma, George, \& Kabir, 2006; Evans, 1995; Musacchio, \& Lazzarini, 2014; Ralston Terpstra-Tong, Terpstra, Wang, \& Egri, 2006). As Kowalski et al. (2013) point out, the shares of SOEs among the Forbes Global 2000 companies currently exceed 50\% for China, India and Indonesia; and are at 39 and 19\% for Russia and Brazil, respectively. Given these figures, it is important for businesses to consider the 
frequency and level of government interventions, as well as the overall stability of the political environment in their operational decisions. As studies have shown, emerging market governments may be more susceptible to external conflicts, coups, and internal tensions - which can create a difficult operating environment for companies (Hiatt \& Sine, 2014). Figure 3 documents the different types of political regimes that exist across emerging economies.

[Insert Figure 3 about here]

Other important differentiating factors include greater informality and less developed government and regulatory infrastructures in emerging economies. At a basic level, both regulatory and enforcement environments are only marginally developed, such that market regulation, corporate governance, transparency, accounting standards, and intellectual property protection may not be as reliable or mature as those in more advanced economies (Marquis, Zhang \& Zhou, 2011; Marquis \& Qian, 2014). Under these conditions, corruption and opportunistic behavior may be especially problematic. Thus, international firms doing business in emerging markets frequently turn to detailed contracts to govern their joint ventures (Luo, 2002).

Beyond differences in political and legal institutions, there are critical differences in the socio-cultural environment of emerging economies. Emerging economies, in particular, tend to be characterized by a younger population, an expanding workforce, and rapid urbanization. These factors have important implications for day-to-day business operations, including marketing and promotion strategies, staffing and training, and consumer preferences. In addition, many socio-cultural issues in emerging economies are ideologically fuelled - suggesting that some of the parties involved may have an interest in sustaining rather than resolving conflicts (Lamertz et al. 2003; Mahon, Heugens, \& Lamertz, 2004). It is therefore crucial for businesses to 
be aware of, and attentive to, issues such as income inequality and poverty, gender inequality, and ethnic and linguistic factionalization - issues that can easily trigger social turmoil and upheaval (Ault \& Spicer, 2014).

Lastly, emerging economies typically have less developed or inadequate technological and physical infrastructures as compared to developed economies. For example, inadequate communication technology, commercial and transportation infrastructures, power generation capabilities, and distribution channels are critical challenges that businesses need to consider and overcome (Hitt, Dacin, Levitas, Arregle, \& Borza, 2000; Miller, 1998).

As the discussion above clearly shows, there are important differences in the economic and institutional conditions of emerging and developed market economies. Of course there are also differences among emerging economies themselves - for example, those noted between traditional developing economies and transitional economies. As Wright et al. (2005: 27) note, it is "not clear whether experience from centrally planned economies in transition applies to those emerging economies that have not followed this trajectory." Yet, despite such differences, there are important similarities that provide common ground for the types of institutional strategies, which may be effective or appropriate in these contexts.

Our approach in this review goes beyond identifying target markets of opportunity for global investors; and, instead, focuses on identifying the key institutional challenges that are generalizable across emerging economy contexts. In doing so, we aim to classify the types of strategies that have been advanced for addressing these challenges and the implications that these strategies have on an organization's operations and strategic focus. We foreground the importance of institutional strategies in emerging markets because these are contexts where the economy and society are coevolving at a rapid rate (Luo, 2006). As Hoskisson et al., (2000:252) 
point out, "government and societal influences are stronger in these emerging economies than in developed economies." Not only is it well known that in these contexts the government is a key constraint - often applying a heavy hand in shaping economic growth trajectories and associated business activity; but the lack of well-established legal and market infrastructures has pushed organizations to adopt a strategic perspective that encompasses both market imperatives and social and cultural concerns.

Table 2 describes in more detail the key dimensions by which emerging contexts vary from developed contexts. These critical variations have important theoretical and practical implications. On a theoretical level, the large-scale institutional changes that often characterize emerging market contexts embody complex economic and social processes that are still little understood (Roland, 2000) - which has prompted calls for more research adopting institutional perspectives (Child \& Lu, 1996; Hoskisson et al., 2000; Peng, 2003; Peng \& Zhou, 2005). On a practical level, a better understanding of these critical variations will help organizations navigate the complex challenges of emerging market contexts, such as increased transaction costs, market vulnerabilities to large macroeconomic and political instabilities, underdeveloped or missing infrastructures (Mair \& Marti, 2009; Mair, Marti and Ventresca 2012), and rampant opportunistic behavior, bribery, and corruption (Cuadra \& Sapriza, 2008; Hoskisson et al., 2000; Wright et al., 2005). These unique sets of challenges underscore the importance of recognizing and attending to key institutional factors that shape the business landscape of emerging economies.

[Insert Table 2 about here]

INSTITUTIONAL STRATEGIES IN EMERGING MARKETS 
To compete effectively in the $21^{\text {st }}$ century, firms in both emerging and developed economies have to be more sensitive to local environments and to their idiosyncratic institutional demands. Since the 1990s, organizations have increasingly been exposed to a diverse set of political, social and cultural environments. Yet theory, until recently, has mainly focused on how such environments become increasingly similar owing to the homogenizing pressures of globalization (Meyer et al., 1997). Our perspective is that local and regional differences will persist, creating variegated challenges for organizations as they expand into new markets and engage in cross-border partnerships (Marquis \& Battilana, 2009).

After reviewing literature spanning various disciplines including strategy, international business, political science, entrepreneurship and organization studies, we found that institutional strategies can be broadly categorized along three dimensions: relational, infrastructure-building, and socio-cultural bridging. While our identification of these different strategies emerged from our review of the literature, we note that they also generally correspond to prior typologies of institutional variation (e.g. Scott, 2014; Busenitz, Gómez, \& Spencer, 2000). A key difference between our conceptualization and this prior work, however, is that our typology is grounded in action-oriented strategies as opposed to descriptive classifications of the underlying dimensions of institutions and institutional environments.

Relational strategies refer to the integrated set of organizational activities directed at managing relationships with important referent audiences. These strategies include networking efforts to manage dependency relationships with the government (Marquis \& Qian, 2014; Siegel, 2007) and key stakeholder groups such as employees, suppliers, and customers (Freeman, 1984; Harrison, Bosse, \& Phillips, 2010). Infrastructure building strategies are those designed to address marginally developed markets, and underdeveloped social, technological, and physical 
infrastructures. For example, where institutions are missing or inadequate, firms frequently utilize strategies such as collective action (King \& Pearce, 2010; Walker and Rea, 2014) and defining global or industry standards (Bartley, 2007) to address such challenges. Socio-cultural bridging refers to strategies that tackle the socio-cultural and demographic issues that can be challenging for organizations - which, for emerging economies, include managing and training younger populations and attending to ideologically-fueled tension and social unrest. In the following section, we develop the conceptualization of the three types of strategies furtherdetailing how they have been discussed in the literature and the relative appropriateness of particular strategies in emerging economy contexts.

\section{Relational Strategies}

A critical dimension of an organization's institutional strategizing relates to how it interacts with and manages important referent audiences. Through effective management of relationships with both internal and external actors, organizations can not only enhance their competitive position in the market (Berman et al., 1999; Heugens et al., 2002; Hillman et al., 1999; Ibarra, 1992; Poldony, 1993), but also ensure the stability and certainty of its resource exchanges (Casciaro \& Piskorski, 2005; Pfeffer \& Salancik, 1978). Two interrelated streams of research have provided strong empirical support for these claims - namely, stakeholder management and corporate political strategy. Studies in these traditions have underscored the importance of the target, prioritization, and timing of an organization's relational strategies.

Research on stakeholder management suggests that an organization should take a broad view of its dependence relationships - to include "any group or individual who can affect or is affected by the achievement of an organization's objectives" (Freeman, 1984: 46). Ample anecdotal and empirical evidence suggests that effective management of 'primary' stakeholder 
groups has a positive impact on financial performance (Berman, Wicks, Kotha, \& Jones, 1999; Laplume, Sonpar, \& Litz, 2008; Waddock \& Graves, 1997), organizational learning and innovation (Heugens et al., 2002; Harting Harmeling \& Vankataraman, 2006), and the development of intangible assets (Hillman \& Keim, 2001). Conversely, failure to attend to key stakeholder concerns has been shown to irreparably damage an organization's legitimacy, and threaten its profitability and growth potential (Berman et al., 1999; Clarkson, 1995; Donaldson \& Preston, 1995; Freeman, Wicks, \& Parmar, 2004).

Studies on stakeholder theory have also revealed that corporations strategically manage diverse stakeholder groups - prioritizing them depending on their power, legitimacy, and the extent to which they can muster a sense of urgency in their demands (Mitchell et al., 1997). From an instrumental perspective, being embedded in a network of stakeholders "acting as a complex system for exchanging goods, services, information, technology, talent, influence, money, and other resources" (Harrison et al., 2010: 60) provides organizations with an opportunity to shape stakeholder relations to their competitive advantage. As Henisz, Dorobantu, and Nartey's (2013) study of the global mining industry demonstrated, companies carefully manage external relations as a means to "reduce opportunistic hold-up by stakeholders" with whom the firm has no direct ties, but whose cooperation is needed for the firm to "create and capture value."

Research on corporate political strategy explores a specific dependence relationship - that between business and the government. Studies in this tradition show that the increasing complexity and pervasive influence of government policies in the market economy have made navigating the public policy arena a top priority for many organizations. This trend has led to growing scholarly interest in the area of corporate political activity (CPA), defined as a set of activities aimed at shaping or producing public policy outcomes that are favorable to a firm's 
continued economic survival and success (De Figueiredo \& Tiller, 2001; Keim \& Baysinger, 1988; Schuler, 1996). Indeed, there has been a proliferation of research documenting the antecedents of corporate political activity at various levels of analysis (for a review, see Hillman, Keim \& Schuler, 2004; and Lux, Crook, \& Woehr, 2011), the types of political strategies and tactics organizations deploy (e.g. Gao, 2006; Oliver \& Holzinger, 2008; Jia, 2014; Weidenbaum, 1980; Zhao, 2012; Walker \& Rea, 2014), and the resultant outcomes of CPA on public policy (Choi, Jia \& Lu, 2014; Campbell, 1998; Dean, Vryza, \& Fryxell, 1998; Holburn \& Vanden Bergh, 2008; Keim \& Zardkoohi, 1988; Lord, 2000; Ramirez \& Eigen-Zucchi, 2001) and firm performance (Cook \& Fox, 2000; Hiatt \& Park, 2013; Lux et al., 2011; Shaffer, Quasney, \& Grimm, 2000).

Insights from this body of research suggest that firms direct their CPA to react to, anticipate, defend against, or proactively shape public policy arenas and political demands (Oliver \& Holzinger, 2008; see also, Bonardi, Holburn, \&Vanden Bergh, 2006; Hillman et al., 2004; Weidenbaum 1980). Other studies have found that by strategically managing businessgovernment relations, firms can enhance political legitimacy, receive preferential policy status, and gain access to critical state resources (Hillman et al., 2004; Marquis \& Qian, 2014; Zhao, 2012). Thus, as the magnitude and scope of government policies continue to expand into nearly every aspect of business (Keim \& Hillman, 2008), effective strategic political management becomes a critical factor in a firm's current and future competitive position (Hillman \& Hitt, 1999; Oliver \& Holzinger, 2008; Yoffie, 1988) - because, as Weidenbaum (1980: 46) aptly notes, public policy is no longer a "spectator sport for business." Barley (2007: 201) goes further, warning that organizations "now wield inordinate political power," enabling them to "undermine 
representative democracy and the public good: promoting legislation that benefits corporations at the expense of individual citizens."

Relational strategies in emerging economies. Much of the literature to date in these areas has explicitly focused on developed market economy contexts - with little attention paid to the relative applicability of these strategies in contexts characterized by weak or underdeveloped market structures, poorly specified property rights, frequent government interventions, and vulnerabilities to political and social instability. Relational strategies that are effective in developed economy contexts may be ill-suited for, or misaligned with, the idiosyncratic conditions of an emerging market economy context. Peng, Wang, and Jiang (2008: 930), for example, argue that while research in developed economies indicate that some firms actively seek to shape the 'rules of the game' in their favor, such political strategies may be less effective in emerging economies, given their "generally nontransparent political and regulatory environment." That is, rather than proactively seeking to influence public policy, organizations may focus their political strategies on furthering their own self-interests - e.g. getting government subsidies, licenses, and tax exemptions (Hillman et al., 2004; Okhmatovskiy, 2010). Because the government typically has a high degree of control over key factors of production, market access and valuable natural resources, effective management of these resource dependences may be more critical to an organization's performance and long-term viability than in developed market economy contexts (Peng \& Heath, 1996; Peng \& Luo, 2000).

A nascent, but growing, body of research has highlighted the importance of interpersonal networks, social capital, and informal institutions in contexts of 'institutional uncertainty', wherein social norms, trust, and personal ties are critical in facilitating cooperation and regulation of social behavior (Peng et al., 2008; Chung, 2006; Kostova \& Roth, 2002; Luo \& 
Chung, 2005; Puffer \& McCarthy, 2007; Webb, Tihanyi, Ireland, \& Sirmon, 2009; Zhu \& Chung, forthcoming). Peng and Luo (2000), for example, found that managers relied heavily on interpersonal networks as informal substitutes for weak market structures - using alliances and inter-organizational agreements to both grow the firm and assure that the terms of a transaction would be met by the parties involved. Similarly, Nee (1992: 10) documented that in socialist states many private firms depended upon informal sources of credit and close ties with local governments in order to compensate for "restrictions on factor resources and the continuing pariah-like status of capitalists and merchants." Such political savvy has been found to be particularly consequential in emerging economies, where rule of law is absent, regulations can change quickly and the risk of expropriation and government intervention is relatively high.

These studies suggest that the integration of corporate political strategies with market strategies is of critical importance in emerging economies because boundaries between government and business spheres are often blurred (Hiatt \& Sine, 2014; Keim \& Hillman, 2008; Wang, 2014). As Melewar, Badal, and Small's (2006) study of Danone's entry into China showed, political sensitivity toward power relations and the need to win (and keep) the goodwill of influential people in business and politics was crucial in gaining market acceptance. Puffer, McCarthy, and Boisot (2010) similarly demonstrated that entrepreneurs relied heavily upon 'blat' and 'guanxi' - i.e. informal connections and relationships based on reciprocity and exchange of favors within Russia and China, respectively - to help reduce uncertainty, protect private property and ownership rights, and facilitate business transactions. These types of informal networks and cultural institutions are especially critical in contexts where formal legal and regulatory institutions that support business activities are underdeveloped or missing. 
While up to this point, we have emphasized the benefits and advantages of close ties with the government and other political actors, there is a growing body of research suggesting that such ties are associated with a number of vulnerabilities and constraints. For example, studies have shown that direct ties to the government may expose an organization to strong pressures to divert its resources to advance political goals and agendas (Okhmatovskiy, 2010; Marquis \& Qian, 2014). Nee and Opper (2010) point out that state-owned firms with connections to political elite have been found to perform worse than private firms because they may be forced to maintain higher employment levels (see also, Fan, Wong, \& Zhang, 2007; and Shleifer \& Vishny, 1994). Similarly, Child and Lu (1996) showed that the economic reform of large stateowned enterprises in China was hindered by constraints associated with close ties to the government. Such findings echo those of Kozhikode an Li (2012), who revealed that commercial banks in India that were either owned or dependent on the government were not able to take advantage of political opportunities to the same extent as their private counterparts. Thus, while politically-connected firms may enjoy a number of advantages over their peers, these advantages may come at a cost - particularly if the value of such connections depreciate or become negative after unexpected political shocks (Sun, Mellahi, \& Thun, 2010: 1162).

On a broader stakeholder level, studies of advanced market economies have highlighted various strategies that firms use to gain stakeholder support, manage stakeholders, and balance stakeholder interests (for a review, see Laplume et al, 2008). Yet, questions remain of "both the desirability and feasibility of introducing or even imposing American-type approaches in emerging economies" (Hoskisson et al., 2000: 263). For instance, while the strategy of balancing the claims of primary stakeholder groups has been argued to optimize firm welfare in developed market economies (Donaldson \& Preston, 1995; Harrison \& St. John, 1996; Walsh, 2005), such a 
strategy may not be effective or feasible in emerging economies. This is likely the case in laborintensive industries, where profit margins are so narrow that simultaneously attending to the demands of multiple audiences may threaten an organization's financial performance and survival as a going concern (Campbell, 2007). Such situations may lead organizations to prioritize the concerns and interests of shareholders above those of customers and the wider public. Julian and Ofori-dankwa (2013), for example, note that while studies undertaken in developed economies posit a positive relationship between firm financial resource availability and corporate social responsibility (CSR) expenditures, they found that the reverse may be true in emerging economies - where the government is focused more on economic development and job creation than CSR; and, where NGOs lack established and/or effective advocacy strategies.

In emerging economies, in other words, the prioritization of stakeholder groups may not be an issue of stakeholders' power or legitimacy (c.f. Mitchell et al., 1997), but rather the "sticks and carrots" inherent in the competitive market environment. Authoritarian regimes such as China and Turkey exercise strict media and Internet censorship and, further, suppress the development of NGOs and consumer watchdog organizations. This leaves few outlets for stakeholders to express their frustrations and concerns - save for boycotts and other forms of private politics (Rodriguez, Siegel, Hillman, \& Eden, 2006). Consequently, stakeholder management in these contexts is likely to require alternative negotiation and communication channels than those typically used (and taken-for-granted) in democratic countries. For instance in the absence of a well-developed NGO sector, Internet activism has become an important mechanism for civil society expression (Luo, Zhang \& Marquis, 2014).

For multinationals operating in emerging economies, another important consideration relates to home country stakeholder concerns. Soule et al. (2014), for example, found that 
pressure from home country stakeholders played a greater role in multinationals' divestment decisions in Burma than did financial considerations or unrealized business opportunities. In particular, the nation's human rights abuses and brutal repression of the pro-democracy movement began to have damaging effects on both the image and credibility of multinationals operating in Burma.

Given the important differences in the institutional conditions of emerging and developed market economy contexts, it is critical to consider the relative appropriateness of transposing particular relational strategies and practices across these contexts. Failure to consider the transferability of relational strategies may jeopardize an organization's competitive advantage and destabilize its resource exchanges with government bodies and key stakeholder groups (Berman et al., 1999; Casciaro \& Piskorski, 2005; Hillman et al., 1999).

\section{Infrastructure Building Strategies}

Core to economic and sociological approaches to markets is the importance of an institutional infrastructure to facilitate market interactions and transactions. Presence of both formal and informal "rules of the game" allows for participants without prior interaction to conduct business and transactions in a more predictable and efficient manner. When such infrastructure is absent or limited, there are a number of challenges that need to be overcome. Research on developed markets has posited various mechanisms to address these challenges, including collectively organizing (King \& Pearce, 2010). Studies in this tradition typically draw on social movement theory, particularly the mechanisms of mobilization structures, political opportunity, and framing processes (McAdam, McCarthy \& Zald, 1996). There are many examples of institutional entrepreneurs creating new organizational forms or arrangements to overcome institutional voids (Mair \& Marti, 2009; Schneiberg \& Lounsbury, 2008). Rao (1998), 
for example, traced how the absence of well-defined consumer protections in the early $20^{\text {th }}$ century United States led social entrepreneurs to establish consumer watchdog organizations to advocate for consumer interests. Other studies have also pointed to the rise self-regulation schemes promoted by industry groups such as the chemical industry's Responsible Care Program (Gunningham, 1995; King \& Lenox, 2000); as well as to the myriad of cases where businesses have organized to develop or refine the formal regulatory environment (Davis \& Thompson, 1994; Walker \& Rea, 2014). Such organizing is similar to Lawrence's (1999) idea of membership strategies that involve the definition of rules of membership and their meaning for an institutional community. In all of these cases, groups of actors work to establish a set of rules or guidelines to better define or guide future business interactions.

In addition to highlighting the development of new organizational arrangements and the promotion of regulatory changes, the non-market strategy literature has implicated the importance of standardization strategies that are "concerned with the establishment of technical, legal or informal standards that define what is "normal" for a practice, product, or service." (Lawrence, 1999: 177). One well known set of global standards, for example, is that of the International Standards Organization (ISO), an organization whose goal is to facilitate global commerce through defining consistent standards for business to follow across a wide array of product categories and business processes (Guler, Guillen, \& MacPherson, 2002). Another important international project is the Global Reporting Initiative (GRI), which promotes a standard set of environmental, social and governance metrics for corporations - as a means to encourage companies to report on these items, and to raise awareness of these issues on global level (Etzion, \& Ferraro, 2010; Marquis \& Qian, 2014).

Infrastructure building strategies in emerging economies. A significant research thrust of 
the work on emerging economies focuses on how many elements of the institutional infrastructure to facilitate business that are taken for granted in developed economies are not present or only marginally developed (Khanna \& Palepu, 2010; Mair, Marti \& Ventresca, 2012. As Arnold and Quelch (1998: 9) describe, in emerging economies, "there is little or no reliable market data, nonexistent or poorly developed distribution systems, relatively few communication channels, and both a lack of regulatory discipline and a propensity to change business regulations frequently and unpredictably." Such conditions are problematic because they create additional uncertainty and challenges for firms (Ault \& Spicer, 2014). For one, organizations must contend with underdeveloped physical and commercial infrastructures such as inadequate communication and transportation channels. Luthra, Mangaleswaran and Padhi (2005), for example, note that companies doing business in the Indian market need to overcome the challenges of poor roads and locked seaports, which can make it difficult to transport goods and work with suppliers. In addition, there is often a lack of well-established property rights and intellectual property protection regulations, which pose a significant threat to the competitive advantage of firms - as piracy and patent infringements can "siphon away revenue and damage brand image" (Bird, 2006: 431). And as Uzo and Mair (2014) showed in a study of the Nigerian movie industry, in these contexts, it may not be lack of formal institutions per se, but that emerging market contexts are characterized by an ambiguity in formal institutions, coupled with an availability of informal arrangements.

To address some of these issues, firms frequently develop and rely more heavily on informal mechanisms in their day-to-day operations (Hoskisson et al., 2000; La Porta et al., 1998; Peng \& Heath, 1996). For example, Khanna et al. (2005) described how in countries like China where food safety problems are endemic, supermarket chain Metro has fostered networks 
between farmers and distributors in rural areas in order to improve the quality and reliability of its meats and vegetables. More generally, a long standing set of research on institutional voids, has shown the importance of developing business groups to minimize opportunistic behavior and transaction costs (Khanna \& Palepu, 2000a, 2000b; Khanna \& Rivkin, 2001; Nachum, 2004). Bruton and Ahlstrom (2003) argue that venture capitalists in settings with weak regulatory institutions would be more likely to fund geographically proximate firms as monitoring would be easier and more important in such settings.

A number of studies have also underscored the importance of developing intermediary institutions and processes as a way to address uncertainty. These could include institutions such as credit agencies and standard setting bodies (Khanna \& Palepu, 2010), as well as programs to develop intermediary skills, human capital and relevant expertise. Marquis, Yin and Yang (2013) for instance analyzed how the Chinese government and large companies participated in the creation of a new set of China specific CSR reporting standards and training programs to help Chinese companies implement this new global practice. More generally, London and Hart (2004) found that successful MNCs often incorporate local capacity building such as training programs and advisory services directly into their business models. Other studies have identified the importance of business processes to better manage increased uncertainty. Hiatt and Sine's (2014) study of entrepreneurship in Columbia, for example, showed that the uncertainty caused by violence and unrest could be offset by formal business planning. In general, the lack of intermediaries and intermediary business processes in emerging economies creates a significant constraint on firm activities - often requiring creative action to overcome.

Another type of infrastructure building strategy is the development or promotion of new or global standards in order to foster a common language and understanding of business practices 
and outcomes (Guler et al., 2002). The importance of global standards has attracted international attention as global consumers increasingly focus on labor and environmental conditions in supply chains. For example, Tim Bartley $(2003 ; 2007)$ has a series of studies that examined the evolution of the Forest Stewardship Council, an example of "market-oriented, nongovernmental standards and monitoring systems as a supplement to state regulation" (O’Rourke 2003: 5). Tarnovskaya (2012) showed how Ikea worked directly with World Wildlife Fund, a global nonprofit, to develop responsible forestry management and certification of IKEA's wood suppliers in Russia and China - two contexts where such standards did not exist. The result was a set of practices and tools for not only educating and training suppliers, but also raising awareness throughout the rest of society. Regarding global standards, the GRI standard has dramatically increased the uptake of environmental reporting, yet there are also questions about whether or not the existence of global practice and standards just makes it easier for organizations in emerging markets to only symbolically comply with global norms (Marquis \& Qian, 2014; see also Okhmatovskiy \& David, 2012; and Tilcsik, 2010)).

While one set of strategies helps firms deal with the uncertainty of emerging markets, another set helps them build greater legitimacy within society, as well as in the eyes of key stakeholder groups such as consumers, governments and civil society. When firms compete in non-home country markets, they frequently face an 'illegitimacy discount' (Zimmerman \& Zeitz, 2002), which shapes how they approach the given market (Kostova \& Zaheer, 1999). A common strategy to raise legitimacy is to promote economic and social development (Zhang \& Luo, 2013; Marquis, Zhang, \& Zhou, 2011), which not only helps with the specific brand and image of a particular firm, but also of multinationals more generally. It is important to recognize that consumer preferences in emerging markets may be different from those of consumers in 
home country markets such that corporations must first establish the legitimacy of an entire product category before they can effectively market their specific products. For instance, as Tarnovskaya (2012) showed, to succeed in markets like China, where the concept of modular furniture and consumers assembling furniture was not as institutionalized, Ikea conducted a number of media and marketing campaigns to educate consumers about this type of product.

Where key commercial, technological, and physical infrastructures are missing or underdeveloped, savvy global businesses may step in and build these infrastructures in ways that create competitive advantage. Alternatively, they may bring with them the 'missing' infrastructure - transposing it from home to host countries (Miller, 1998). For businesses, then, it is critical to consider infrastructural gaps and necessities. Yet, at the same time, it is important to keep in mind that emerging economies are undergoing continual and rapid change - such that it may be "misguided short-termism to base corporate strategy on structural conditions that may be subject to rapid change, even though these may be suitable criteria for evaluating investments in emerging-economy stock markets" (Arnold \& Quelch, 1998: 12).

\section{Socio-cultural Bridging Strategies}

It is widely acknowledged that business transactions and operations "do not happen in a vacuum, but in specific social, cultural, and political contexts" (Okhmatovskiy, 2010: 1039). Appreciating the particularities of the socio-cultural environment, and being able to address them accordingly, is a critical part of an organization's daily operations and long-run success (Hillman \& Hitt, 1999; Peng et al., 2008). By adopting socio-cultural bridging strategies, organizations aim to address the socio-cultural and demographic issues (and challenges) that shape their competitive environment. 
In an increasingly integrated global economy, businesses are expected to understand and compete in institutionally diverse settings (Child \& Lu, 1996; Kostova \& Roth, 2002; Palmer, Jennings, \& Zhou, 1993; Peng \& Heath, 1996). Research in international business and strategy, for example, underscores the importance of appreciating and attending to local norms, customs, and historical traditions when embarking on international diversification and cross-boarder partnerships (Hitt, Hoskisson, \& Kim, 1997; Hitt, Tihanyi, Miller, \& Connelly, 2006). Not surprisingly, studies have shown that it is easier for firms to do business in countries where the "social climate is similar to their own" - yet, much of the literature in strategy has "paid less attention to normative and cognitive institutions in favor of studying the regulatory environment" (Hitt et al., 2006: 847). The importance of understanding local contexts has also been emphasized in research on cultural entrepreneurship, which has highlighted how entrepreneurs leverage social and cultural resources to legitimate new organizational structures and practices (Hargadon \& Douglas, 2001; Johnson, 2007; Lounsbury \& Glynn, 2001).

To develop a more comprehensive understanding of the differences across institutional settings, some scholars have advocated a comparison across three types of institutional domains: the regulatory, the cognitive, and the normative (Kostova \& Zaheer, 1999; see also, Busenitz et al., 2000; and Scott, 2008). Kostova and colleagues' work on multinational enterprises argues that the greater the 'institutional distance' between the home and host countries, the more difficult it will be to understand and correctly interpret local institutional requirements. The implication is that organizations will have to increase the extent of adaptation required to better align their practices, strategies, and operations with the host country context (Kostova \& Roth, 2002; Kostova \& Zaheer, 1999). This argument echoes that of Arnold and Quelch (1998: 12), who point out that, managers frequently base decisions to expand operations "not on objective 
market screening but on their own comfort level, choosing a predictable sequence of markets beginning with those closest in 'psychic distance' to their home culture."

For organizations operating in both advanced and emerging market economies, the critical challenge, then, is to navigate a large institutional divide - as the socio-cultural environment in these contexts are very different (Busenitz et al., 2000; Kostova, 1999; Kostova \& Roth, 2002; Xu \& Shenkar, 2002). While research on the varieties of capitalism has endeavored to understand institutional variation across developed nations (Hall \& Soskice, 2001; Whitley, 1999), few studies have systematically examined institutional variation between developed and emerging market economy contexts. In consequence, we know relatively little about the applicability of cultural bridging strategies across these contexts.

Socio-cultural bridging strategies in emerging economies. In emerging economies, organizations need to address a set of complex demographic and socio-cultural issues. As noted earlier, organizations must attend to demographic challenges such as a young workforce, lack of available skilled workers, and increasing urbanization. These challenges may require companies to invest heavily in employee training and development, to bring over experts and managers from the organizations' home countries, and/or to make location decisions based on the availability of skilled labor. Further, as more companies peg their prospects for growth on emerging markets, the "war for talent" intensifies - leaving companies with the challenging task of recruiting and retaining a local workforce that now has more options and higher expectations. (Ready, Hill, \& Conger, 2008). Indeed, there is growing empirical evidence that establishing a core group of local talent is critical to understanding regional conditions and cultural norms. To do so, some companies export talent from their home countries to train local executives and managers - however, this strategy often requires extensive tailoring to succeed (Kostova \& Roth, 
2002; Ready et al., 2008). As Boxenbaum and Battilana (2005) note, transporting managerial practices from one social context to another requires adaptation and, at times, the combination with local practices.

In terms of socio-cultural issues, emerging economies often face a number of challenges including demographic disparities, ideologically-fuelled social unrest, and local hostility toward growing migrant worker populations (James, 2011; Lamertz et al. 2003). To address these sociocultural issues, companies must first develop an adequate knowledge of local socio-cultural conditions and features - which is critical to making informed judgments in day-to-day operations and for long-term strategic planning (Arnold \& Quelch, 1998; Puffer et al., 2010). London and Hart (2004: 364), for example, advocate the importance of social embeddedness, which refers to "the ability to create competitive advantage based on a deep understanding of and integration with the local environment" - namely, by leveraging and building on the existing social infrastructure (see also, Chung \& Luo, forthcoming). Similarly, Luo and Peng (1999: 272) note that local knowledge and experience can provide MNEs with a significant competitive advantage - reflecting an "ownership-specific, intangible asset which can generate economic rents." Gaining such knowledge may require losing some control or delegating authority to local partners. Alternatively, it may require hiring local senior managers and consultants, investing in field investigations, and/or learning from local competitors. In any case, such strategies are often critical to success because socio-cultural misunderstandings or missteps can be very costly - not to mention, result in missed opportunities. As Melewar et al. (2006: 408) point out, companies seeking to expand their operations abroad need to "alter their modes of operation to suit prevailing cultural and market conditions." 
Another important consideration in terms of cultural bridging - particularly in transition economies - is the enduring legacies of past Soviet-style market economies and Communist regimes (Child \& Markoczy, 1993; Kriauciunas \& Kale, 2006; Murrell \& Wang, 1993; PopEleches, 2007; Spicer, McDermott, \& Kogut, 2000). Traces of these legacies can still be seen in the excess physical and human resources characterizing many state-owned, or recently privatized, firms. Peng and Heath (1996) attribute this pattern to the residual Socialist ideology of full employment - which has pressured managers to find uses for excess human resources rather than downsizing. Relatedly, there are still strong societal expectations from the labor force and wider public that organizations provide healthcare, education, and accommodation for employees and their families (Han, Zheng, \& Xu, 2014; Kriauciunas \& Kale, 2006; Zu \& Song, 2009). Addressing these residual expectations is often challenging for organizations because they typically run counter to the logic of capitalism, which stresses the primacy of markets and competition (Tilcsik, 2010). Shaking off Socialist legacies, thus, requires more than changes in market and regulatory infrastructures, but rather fundamental shifts in underlying belief and value systems regarding business-employee relationships, private ownership, profit, and other aspects of a free-market economy.

A greater appreciation of these legacies is critical for understanding how local norms, values, and expectations continue to enable and constrain organizational behavior and strategic action in emerging economies (Han et al., 2014; Kriauciunas \& Kale, 2006). Raynard, Lounsbury, and Greenwood (2013), for example, found that the legacies of China's past political regimes continued to shape how organizations conceptualized, experienced and implemented government-led CSR initiatives. Similarly, Stark (1996: 995) documented how the persistence of 
routines, practices, and networks of affiliation could become "assets, resources, and the basis for credible commitments and coordinated actions in the postsocialist period."

As growing empirical evidence has revealed, firms need to invest significant time and resources to develop sufficient knowledge of local socio-cultural conditions - as countries have idiosyncratic institutional environments that can present a number of challenges for organizations that operate across multiple contexts (Kostova, 1999; Kostova \& Roth, 2002; Xu \& Shenkar, 2002). It is thus critical for organizations to both appreciate and attend to local demographic and socio-cultural issues - because, as Peng et al. (2008: 922) point out, the "treatment of institutions as background is insufficient to gain a deep understanding of strategic behavior and firm performance ... its deficiency becomes even more striking when probing into emerging economies." Oftentimes, the formal and informal rules of the game differ between emerging and advanced economy contexts - such that without an adequate understanding of local institutional conditions, businesses may not only be at a disadvantage but also run into costly legal issues. For example, in China, "executives from competing firms can legally sit down, discuss pricing, and carve up markets - a practice that has been labeled by US antitrust laws as 'collusion' (Peng et al., 2008: 931).

Taking stock of the rich literature on the similarities and differences across institutional contexts will provide a more holistic understanding of the unique pattern of social and cultural factors that shape business-society interactions. For organizations, a better understanding of socio-cultural differences is critical in helping bridge cultural divides that may hinder international expansion and growth - because, as organizational theorists have long contended, responding 'appropriately' to socio-cultural expectations is critical for gaining access to resources, legitimacy, and social approval (Oliver, 1991; Pfeffer \& Salancik, 1978). 
In summary, Table 3 provides the key definition and examples of the three institutional strategies our review uncovered.

[Insert Table 3 about here]

\section{DISCUSSION AND CONCLUSIONS}

Our focus on institutional strategies in emerging economies has a number of important theoretical and practical implications. While much prior work in organizational theory has focused on how external environments shape organizational structures and behavior (Scott \& Davis, 2006; Greenwood et al., 2011), our argument centers on the idea that firms are not merely passive recipients of institutional pressures; but, instead, they interact with and reciprocally shape their institutional contexts. In this review, we focused on identifying the critical factors that enable and constrain institutional strategizing in emerging economy contexts - yet our broader goal was to provide an integrated perspective on institutional strategies that applies to diverse contexts. Synthesizing a wide range of literature from strategy, international business, political science, entrepreneurship and organization studies, our review advances research on emerging markets and institutional theory by highlighting the agentic and intent-driven nature of organizational responses to institutional pressures - and the critical importance of such responses in emerging economy contexts.

\section{Bringing Emerging Markets Research to the Center of Organizational Studies}

Despite growing scholarly interest in examining emerging markets, there are few conceptual models that provide a comprehensive picture of the unique challenges and opportunities facing organizations in these contexts. As Mahon, Heugens, and Lamertz (2004: 170) lament, current research has "has little to offer in the way of a truly integrated perspective 
on the management of non-market forces." By addressing these gaps, we are, in a sense, recommending a sea change in organizational theories - namely, the shifting from an emphasis on traditional developed markets and contexts to integrating emerging economies in how organizational behavior is conceptualized. As Figure 1 clearly shows, emerging market economies are quickly rising to the center of global markets. This important trend underscores the need for organizational studies to develop a perspective and approach to address organizational behavior within and across these markets.

As a first step in this process, we reviewed work that can be considered part of a firm's institutional strategizing, and identified three distinct sets of strategies that can be used to manage relationships with important referent audiences, address missing or underdeveloped infrastructures, and tackle demographic and socio-cultural challenges. From our review, it is clear that there has been a proliferation of research on the various relational strategies that organizations adopt to manage their relationships with political bodies and key stakeholder groups in emerging markets - with less attention being paid to examining infrastructure building and socio-cultural bridging strategies in these contexts. As such, we encourage further research in these particular areas in order to provide a more integrated perspective on the management of non-market forces in these contexts. While we recognize that there are differences across emerging markets, the three categories of institutional strategies identified here provide an important jumping off point for understanding these differences and their implications for organizations.

Future research building on these concepts may address questions such as how and why particular institutional strategies are more (or less) effective across different emerging economies. For instance, one natural grouping under the broader emerging market umbrella is 
the distinction between the traditional developing economies and transition economies. A future line of research could examine the added challenges of implementing relational strategies in transition economies, wherein the previously closed nature of these economies has led most MNCs to have few links to business networks (Arnold \& Quelch, 1998: 9). Related to this, is the question of how legacies of past Socialist and Communist regimes continue to affect the competitive landscape facing organizations in transition economies - as opposed to traditional developing economies (Kriauciunas \& Kale, 2006). As Figure 3 shows, there are a variety of different political systems, each of which could create another layer of difference across these contexts.

Along these lines, a crucial next step is to better define how the institutional capacity of an emerging economy to support corporate activity differs from that of more advanced economies. While we created a baseline set of differences in Table 2, there is significant room for more specific questions. For example, how do the idiosyncratic institutions and conditions that shaped the development of firms from emerging and advanced economies shape their business activities and interaction patterns? Further, assuming that not all emerging economies follow Western-style patterns of economic development, how do differences in developmental trajectories affect the types of institutional strategies selected? Answering such questions will be important to understanding global competition moving forward - for globalization has opened up a "two-way street", wherein businesses from advanced economies are not only expanding and diversifying into emerging markets, but businesses in emerging economies are also increasingly entering developed markets (Luo \& Tung, 2007; Zhang, Duysters \& Filippov, 2012). Guillen and García-Canal (2009: 27) argue that multinationals from emerging economies may have a competitive advantage when expanding into other emerging economies - because they are "more 
used to dealing with discretionary and/or unstable governments in their home country, they are better prepared than the traditional MNEs to succeed in foreign countries characterized by a weak institutional environment." We encourage future research that looks in more detail at the contrast between emerging and developed economies and the implications for organizational studies.

For research on strategy and international business, a more comprehensive understanding of the unique sets of challenges and opportunities posed by emerging market contexts will allow for better informed decisions regarding partner selection, market entry mode, manufacturing location choices, product distribution channels, employee hiring and training policies, and so on. As globalization progresses, organizations need to understand and compete in institutionallydiverse settings - requiring them to implement various institutional strategies to work with and shape relations with both internal and external actors; and, to gain knowledge of, and experience in, various local contexts. Such strategies are critical in mitigating uncertainty and stabilizing resource exchanges - especially in situations characterized by turbulent change, social instability, and frequent government interventions. Next steps in this stream of research may include investigations into how the strategy formulation and implementation processes of organizations operating in emerging markets differ from those of organizations in developed markets.

For research on entrepreneurship in emerging economy markets, appreciating the diverse institutional strategies available for navigating demographic and socio-cultural challenges is important for understanding how entrepreneurs not only gain access to critical start-up capital and resources, but also attend to marginally-developed market, regulatory, technological and physical infrastructures. Recent studies, for example, have shown that property protection and 
intellectual property rights regulations are "essential to entrepreneurship" in developed market economies (Puffer et al., 2010: 443). Yet, in emerging economies, such regulations may be missing or underdeveloped. As a consequence, entrepreneurs in these contexts have had to rely more heavily on specific relational and infrastructure building strategies, such as developing informal connections to local government officials and accessing informal sources of credit (Khanna \& Palepu, 1997; Nee, 1992; Peng \& Luo, 2000).

Finally, for research on marketing, understanding the distinct institutional landscape of emerging market economies is critical for identifying customer tastes and preferences, customer characteristics and buying habits, as well as branding requirements (Arnold \& Quelch, 1998; Melewar et al., 2006). However, developing such an understanding may be difficult due to a lack of reliable market research data and the rapidly changing social and demographic climate. To overcome these challenges will likely require dynamic and continuous monitoring of the marketplace, and a creative use of indicators to serve as "surrogates for assessing demand" (Arnold \& Quelch, 1998: 14). Alternatively, London and Hart (2004) suggest that collaborating with non-traditional partners (e.g. non-profit organizations and community groups), co-inventing custom solutions from the bottom-up, and developing local capacity can provide MNCs with information on the local context, legitimacy, and access to needed resources.

Overall, the above sets out new research directions aimed to promote cross-disciplinary dialogue, and to explore how organizations strategically navigate and manage the increasing complexities of their institutional environments. We encourage further research on emerging economies that integrates different theoretical lenses - as a means to better understand how these important contexts shed new light on existing organizational theories as well as conventional wisdom in academic thinking (c.f. Wright et al., 2005). 


\section{Institutional Theory: A New Frontier}

Our conceptualization of institutional strategies also has important contributions to defining a new frontier of research on institutional theories. As globalization proceeds and emerging markets continue their remarkable growth trajectory, institutional theory has increasingly been drawn upon to provide crucial insights into the affects of institutional variation on organizational behavior and performance (Greenwood et al., 2011). Strategy scholars, for example, have underscored the importance of both understanding and adapting to institutional variations (Ahuja \& Yayavaram, 2011; Peng et al., 2008) - yet, the implication of our review is that organizations may need to undertake a greater variety of strategies to align their practices and operations with different host country contexts (Kostova \& Roth, 2002).

Such a shift requires movement away from top down, passive conceptualizations of institutions to a more bottom-up interactive perspective that recognizes that organizations must be strategic in shaping their external contexts. And, while a long-standing criticism of institutional theory is its inability to explain endogenous change and agentive behavior, several streams of research have emerged to address this concern - e.g. institutional entrepreneurship (Battilana, et al, 2009), cultural entrepreneurship (Lounsbury \& Glynn, 2001), and institutional work (Lawrence, Suddaby \& Leca, 2011). Research from the institutional logics perspective, for instance, typically adopts a dynamic constructionist stance, wherein actors exposed to heterogeneous institutional arrangements have the "reflective capacity to innovate and create institutional change" (Thornton et al., 2012: 110). These newer streams of research have provided important insights into the "paradox of embedded agency," addressing how organizations maintain their existing position in current institutional structures, whilst managing 
and building upon the institutions around them (Battilana \& D'Aunno, 2009; Hargadon \& Douglas, 2001).

In this review, we adopted a slightly different approach by highlighting a more interactive view of institutional processes that complements traditional perspectives. Because the prior literatures on which we built have not typically been considered under the institutional theory ambit, they have not been shaped by implicit assumptions that actors are constrained in their institutional actions. In reviewing and synthesizing these cognate literatures, our intention was to identify the agentic and intent-driven nature of organizational strategies, which help shape and construct their institutional contexts.

Our focus on emerging economy contexts drew attention to two key areas for future research. First, we highlighted the need for a greater appreciation of the institutionally-diverse contexts confronting organizations. To effectively compete and survive in today's complex and globally-integrated market economy, organizations must not only be able to identify the unique sets of opportunities and challenges within these diverse contexts, but also attend to the idiosyncratic socio-political and cultural issues that characterize them. In many ways, our theoretical toolkits have been dominated by observations of, and insights derived from, developed market contexts - leading them to be somewhat misaligned with the current reality facing corporations. In order to keep pace with the current reality, we need to be open to challenging long-standing assumptions, testing existing theories, and developing new theories to account for the diversity of the global market. We, thus, echo Scott's (2005) call for more institutional research examining non-Western cases - as part of a broader effort to test the generalizability of extant models and theories. 
Second, our review revealed the need for more dynamic conceptual models of the institutional pressures exerted on organizations. For the most part, current institutional theorizing has been grounded in rather static "snapshots" of a particular organizational or industry context over a relatively short period of time (Davis, 2010). Such snapshots may be inappropriate, or worse, misleading, when applied to emerging economies - which are characterized by fast-paced turbulent change. We, thus, suggest the need to develop dynamic strategy repertoires that enable organizations to learn, reconfigure, and adapt strategies in response to rapidly changing conditions (Eisenhardt \& Martin, 2000; Wright et al., 2005). In doing so, we echo Tilcsik (2010), who argues that future research should examine organizational "responses and the actors who implement them in motion, exploring how responses are formulated, contested, and altered over time" (p. 1493, emphasis original).

In advocating this new frontier of institutional scholarship, we aim to highlight the importance of collaboration and discussion across disciplines, and the need to appreciate the myriad of institutional landscapes that organizations currently face. Thus, while our review focused on institutional strategizing in emerging economy contexts, we believe the insights generated herein have broader applicability for theorizing about advanced economies - and for building institutional theory more generally. For example, insights regarding the effectiveness of a particular institutional strategy in emerging economies may be generalizable to developed economies under various conditions - such as a partnership or collaboration between firms from both contexts, and the management of global supply chain relationships. Moreover, as the global economy becomes more integrated and the conditions in emerging economies move closer to those of advanced economies, organizations' repertoires of institutional strategies are likely to evolve and possibly converge - blurring the lines between strategies tailored for emerging and 
developed economy contexts. This, however, is an empirical question that requires further research to confirm.

Finally, we propose that the categories of institutional strategies that we identified from research on emerging economies - relational, infrastructure-building and socio-cultural bridging - may be usefully applied to advanced economies. For companies operating in advanced economies must also develop a repertoire of institutional strategies for navigating their sociocultural and political institutions. We encourage further cross-fertilization of research from emerging and developed market contexts - as a means to build more general and practical theory.

\section{$\underline{\text { Conclusion }}$}

By bringing together diverse streams of research under the umbrella of 'institutional strategies', we draw attention to a number of important research opportunities. The core contribution of this article is that it maps the field of research on institutional strategies, and highlights potential avenues for future research. As our review showed, there is a biased selection and focus in current research - namely, a disproportionate emphasis on developed markets. This raises some concern regarding the applicability of current models and theoretical toolkits in the context of emerging markets. To address this concern, we offer up a comprehensive framework of institutional strategies that not only provides a more realistic account of the diverse institutional conditions that organizations confront, but also highlights the importance of expanding the current focus from developed markets to a more global perspective. Our hope is that by outlining future research directions and raising provocative research questions, our review will encourage scholars to challenge and test existing theories, and to engage in more fruitful cross-disciplinary dialogue. 


\section{REFERENCES}

Ahuja, Gautam, and Sai Yayavaram. Explaining influence rents: The case for an institutionsbased view of strategy. Organization Science 22.6 (2011): 1631-1652.

Arnold, D. J., \& Quelch, J. A. (1998). New Strategies in Emerging Markets. Sloan Management Review, 40(1), 7-20.

Ault, J. K. \& Spicer, A. Forthcoming The institutional context of poverty: State fragility as a predictor of cross-national variation in commercial microfinance lending. Strategic Management Journal.

Baron, D. P. (1995). Integrated Strategy: Market and Nonmarket Components. [Article]. California Management Review, 37(2), 47-65.

Bartley, T. (2003). Certifying Forests and Factories: States, Social Movements, and the Rise of Private Regulation in the Apparel and Forest Products Fields. Politics \& Society, 31(3), 433-464.

Bartley, T. (2007). How Foundations Shape Social Movements: The Construction of an Organizational Field and the Rise of Forest Certification. Social Problems, 54(3), 229255.

Battilana, J., \& D'Aunno, T. (2009). Institutional work and the paradox of embedded agency. In T. B. Lawrence, R. Suddaby \& B. Leca (Eds.), Institutional work: Actors and agency in institutional studies of organizations (pp. 31-58). New York: Cambridge University Press.

Battilana, J., Leca, B., \& Boxenbaum, E. (2009). How Actors Change Institutions: Towards a Theory of Institutional Entrepreneurship. The Academy of Management Annals, 3, 65107.

Berman, S. L., Wicks, A. C., Kotha, S., \& Jones, T. M. (1999). Does Stakeholder Orientation Matter? The Relationship between Stakeholder Management Models and Firm Financial Performance. The Academy of Management Journal, 42(5), 488-506.

Bird, R.C. (2006). The impact of coercion on protecting US intellectual property rights in the BRIC economies. In S.C. Jain (Ed.), Emerging economies and the transformation of international business: Brazil, Russia, India and China (BRICs) (pp. 431-451). Edward Elgar Publishing.

Bonardi, J. P., Holburn, G. L., \& Vanden Bergh, R. G. V. (2006). Nonmarket strategy performance: Evidence from US electric utilities. Academy of Management Journal, 49(6), 1209-1228.

Boxenbaum, E., \& Battilana, J. (2005). Importation as innovation: Transposing managerial practices across fields. Strategic Organization, 3(4), 355-383.

Bruton, G. D., \& Ahlstrom, D. (2003). An institutional view of China's venture capital industry: Explaining the differences between China and the West. Journal of Business Venturing, 18(2), 233-259.

Busenitz, L. W., Gómez, C., \& Spencer, J. W. (2000). Country Institutional Profiles: Unlocking Entrepreneurial Phenomena. Academy of Management Journal, 43(5): 994-1003. 
Campbell, J. L. (1998). Institutional Analysis and the Role of Ideas in Political Economy. Theory and Society, 27(3), 377-409.

Campbell, J. L. (2007). Why Would Corporations Behave in Socially Responsible Ways? An Institutional Theory of Corporate Social Responsibility. Academy of Management Review, 32(3), 946-967.

Carroll, G. R., \& Swaminathan, A. (2000). Why the Microbrewery Movement? Organizational Dynamics of Resource Partitioning in the U.S. Brewing Industry. The American Journal of Sociology, 106(3), 715-762.

Casciaro, T., \& Piskorski, M. J. (2005). Power Imbalance, Mutual Dependence, and Constraint Absorption: A Closer Look at Resource Dependence Theory. Administrative Science Quarterly, 50(2), 167-199.

Chang, S.-J., Chung, C.-N., \& Mahmood, I. P. (2006). When and how does business group affiliation promote firm innovation? A tale of two emerging economies. Organization Science, 17(5): 637-656.

Child, J., \& Lu, Y. (1996). Institutional Constraints on Economic Reform: The Case of Investment Decisions in China. Organization Science, 7(1), 60-77.

Child, J., \& Markóczy, L. (1993). Host-country Managerial Behaviour and Learning in Chinese and Hungarian Joint Ventures. [Article]. Journal of Management Studies, 30(4), 611-631.

Chung, H.-M. (2006). Managerial ties, control and deregulation: An investigation of business groups entering the deregulated banking industry in Taiwan. Asia Pacific Journal of Management, 23(4), 505-520.

Chung, C. N., \& Luo, X. (2013). Leadership succession and firm performance in an emerging economy: Successor origin, relational embeddedness, and legitimacy. Strategic Management Journal, 34(3), 338-357.

Choi S-J, Jia N, Lu J. 2014. The Structure of political institutions and effectiveness of corporate political lobbying. Organization Science. Forthcoming

Clarkson, M. B. E. (1995). A Stakeholder Framework for Analyzing and Evaluating Corporate Social Performance. The Academy of Management Review, 20(1), 92-117.

Cook, R. G., \& Fox, D. R. (2000). Resources, Frequency, and Methods: An Analysis of Small and Medium-Sized Firms' Public Policy Activities. Business \& Society, 39(1), 94-113.

Cuadra, G., \& Sapriza, H. (2008). Sovereign default, interest rates and political uncertainty in emerging markets. Journal of International Economics, 76(1), 78-88.

Davis, G. F. (1991). Agents without Principles? The Spread of the Poison Pill through the Intercorporate Network. Administrative Science Quarterly, 36(4), 583-613.

Davis, G. F. (2010). Do Theories of Organizations Progress? Organizational Research Methods, 13(4), 690-709.

Davis, G. F. and Marquis, C. (2095). Prospects for Organizational Theory in the Early 21st Century: Institutional Fields and Mechanisms." Organization Science 16, no. 4: 332-343.

Davis, G. F., \& Thompson, T. A. (1994). A Social Movement Perspective on Corporate Control. Administrative Science Quarterly, 39(1), 141-173. 
Davis, G. F., McAdam, D., Scott, W. R., \& Zald, M. N. (Eds.). (2005). Social movements and organization theory. New York: Cambridge University Press.

De Figueiredo, J. M., \& Tiller, E. H. (2001). The structure and conduct of corporate lobbying: how firms lobby the Federal Communications Commission. Journal of Economics \& Management Strategy, 10(1), 91-122.

Dean, T. J., Vryza, M., \& Fryxell, G. E. (1998). Do Corporate PACs Restrict Competition?: An Empirical Examination of Industry PAC Contributions and Entry. Business \& Society, 37(2), 135-156.

DiMaggio, P. J., \& Powell, W. W. (1983). The Iron Cage Revisited: Institutional Isomorphism and Collective Rationality in Organizational Fields. American Sociological Review, 48(2), 147-160.

Donaldson, T., \& Preston, L. E. (1995). The stakeholder theory of the corporation: Concepts, evidence, and applications. Academy of Management Review, 20(1), 65-91.

Douma, S., George, R., \& Kabir, R. (2006). Foreign and domestic ownership, business groups, and firm performance: evidence from a large emerging market. Strategic Management Journal, 27(7), 637-657.

Eisenhardt, K. M., \& Martin, J. A. (2000). Dynamic capabilities: What are they? Strategic Management Journal, 21(10-11), 1105-1121.

Etzion, D., \& Ferraro, F. (2010). The Role of Analogy in the Institutionalization of Sustainability Reporting. Organization Science, 21(5), 1092-1107.

Evans, P. 1995. Embedded autonomy: States and industrial transformation. Princeton, NJ: Princeton University Press.

Fan, J. P. H., Wong, T. J., \& Zhang, T. (2007). Politically connected CEOs, corporate governance, and Post-IPO performance of China's newly partially privatized firms. Journal of Financial Economics, 84(2), 330-357.

Fligstein, N. (1985). Spread of the Multidividional Form Among Large Firms, 1919-1979. American Sociological Review, 50(3), 377-391.

Freeman, R. E. (1984). Strategic management: A stakeholder approach. Boston: Pitman.

Freeman, R. E., Wicks, A. C., \& Parmar, B. (2004). Stakeholder Theory and "The Corporate Objective Revisited". Organization Science, 15(3), 364-369.

Friedland, R., \& Alford, R. R. (1991). Bringing society back in: Symbols, practices and institutional contradictions. In W. W. Powell \& P. J. DiMaggio (Eds.), The new institutionalism in organizational analysis (pp. 232-262). Chicago: The University of Chicago Press.

Galaskiewicz, J. (1985). Social Organization of an urban grants economy: A study of business philanthropy and nonprofit organizations. Orlando, FL: Academic Press.

Galaskiewicz, J., \& Wasserman, S. (1989). Minetic Processes Within an Organizational Field: And Empirical Test. Administrative Science Quarterly, 34, 454-479.

Gao, Y. (2006). Corporate political action in China and America: a comparative perspective. [Article]. Journal of Public Affairs (14723891), 6(2), 111-121. 
Greenwood, R., \& Suddaby, R. (2006). Institutional Entrepreneurship in Mature Fields: The Big Five Accounting Firms. Academy of Management Journal, 49(1), 27-48.

Greenwood, R. O., \& Sahlin, C. K. \& Suddaby, R. (2008). Introduction. In R. Greenwood, C. Oliver, R. Suddaby \& K. Sahlin-Andersson (Eds.), The Sage Handbook of Organizational Institutionalism (pp. 1-46). London: Sage Publications Ltd.

Greenwood, R., Raynard, M., Kodeih, F., Micelotta, E. R., \& Lounsbury, M. (2011). Institutional Complexity and Organizational Responses. The Academy of Management Annals, 5(1), 317-371.

Guillén, M. F., \& García-Canal, E. (2009). The American model of the multinational firm and the "new" multinationals from emerging economies. Academy of Management Perspectives, 23(2), 23-35.

Guler, I., Guillén, M. F., \& Macpherson, J. M. (2002). Global Competition, Institutions, and the Diffusion of Organizational Practices: The International Spread of ISO 9000 Quality Certificates. Administrative Science Quarterly, 47(2): 207-232.

Gunningham, Neil. (1995). "Environment, Self-Regulation, and the Chemical Industry: Assessing Responsible Care." Law \& Policy 17:57-101.

Hall, P. A. (1986). Governing the economy: the politics of state intervention in Britain and France. New York: Oxford University Press.

Hall, P. A., \& Soskice, D. W. (2001). Varieties of capitalism: The institutional foundations of comparative advantage. New York: Oxford University Press.

Han, Y., Zheng, E., \& Xu, M. (2014). The Influence from the Past: Organizational Imprinting and Firms' Compliance with Social Insurance Policies in China. Journal of Business Ethics, 122(1), 65-77.

Hargadon, A. B., \& Douglas, Y. (2001). When innovations meet institutions: Edison and the design of the electric light. Administrative Science Quarterly, 46(3), 476-501.

Harrison, J. S., \& St John, C. H. (1996). Managing and partnering with external stakeholders. [Article]. Academy of Management Executive, 10(2), 46-60.

Harrison, J. S., Bosse, D. A., \& Phillips, R. A. (2010). Managing for stakeholders, stakeholder utility functions, and competitive advantage. Strategic Management Journal, 31(1), 5874.

Harting, T. R., Harmeling, S. S., \& Venkataraman, S. (2006). Innovative Stakeholder Relations: When "Ethics Pays" (And When It Doesn't). Business Ethics Quarterly, 16(1), 43-68.

Henisz, W. J., Dorobantu, S., \& Nartey, L. J. (2014). Spinning gold: The financial returns to stakeholder engagement. Strategic Management Journal, forthcoming.

Henisz, W. J., \& Zelner, B. A. (2003). The Strategic Organization of Political Risks and Opportunities. Strategic Organization, 1(4), 451-460.

Heugens, P. P. M. A. R., van den Bosch, F. A. J., \& van Riel, C. B. M. (2002). Stakeholder Integration: Building Mutually Enforcing Relationships. Business \& Society, 41(1), 3660 . 
Hiatt, S. R. \& Park, S. (2013). Lords of the harvest: Third-party influence and regulatory approval of genetically modified organisms. Academy of Management Journal, 56(4): 923-944.

Hiatt, S. R., \& Sine, W. D. (2014). Clear and present danger: Planning and new venture survival amid political and civil violence. Strategic Management Journal, 35(5), 773-785.

Hiatt, S. R. \& Sine, W. D. 2014. Manu Militari: Venture Ties to Coercive Institutions in Emerging Economies, Working paper. Los Angeles, CA: University of Southern California.

Hillman, A. J., \& Hitt, M. A. (1999). Corporate Political Strategy Formulation: A Model of Approach, Participation, and Strategy Decisions. [Article]. Academy of Management Review, 24(4), 825-842.

Hillman, A. J., \& Keim, G. D. (2001). Shareholder value, stakeholder management, and social issues: What's the bottom line? Strategic Management Journal, 43(4), 717-736.

Hillman, A. J., Keim, G. D., \& Schuler, D. (2004). Corporate Political Activity: A Review and Research Agenda. Journal of Management, 30(6), 837-857.

Hillman, A. J., Zardkoohi, A., \& Bierman, L. (1999). Corporate Political Strategies and Firm Performance: Indications of Firm-Specific Benefits from Personal Service in the U.S. Government. Strategic Management Journal, 20(1), 67-81.

Hirsch, P. M., \& Lounsbury, M. (1997). Ending the Family Quarrel: Towards a Reconciliation of 'Old' and 'New' Institutionalism. American Behavioral Scientist, 40(4), 406-418.

Hitt, M. A., Dacin, M. T., Levitas, E., Arregle, J.-L., \& Borza, A. (2000). Partner Selection in Emerging and Developed Market Contexts: Resource-Based and Organizational Learning Perspectives. The Academy of Management Journal, 43(3), 449-467.

Hitt, M. A., Hoskisson, R. E., \& Kim, H. (1997). International Diversification: Effects on Innovation and Firm Performance in Product-Diversified Firms. The Academy of Management Journal, 40(4), 767-798.

Hitt, M. A., Tihanyi, L., Miller, T., \& Connelly, B. (2006). International Diversification: Antecedents, Outcomes, and Moderators. Journal of Management, 32(6), 831-867.

Holburn, G. L., \& Bergh, R. G. V. (2008). Making friends in hostile environments: Political strategy in regulated industries. Academy of Management Review, 33(2), 521-540.

Hoskisson, R. E., Eden, L., Lau, C. M., \& Wright, M. (2000). Strategy in Emerging Economies. [Article]. Academy of Management Journal, 43(3), 249-267.

Ibarra, H. (1992). Homophily and Differential Returns: Sex Differences in Network Structure and Access in an Advertising Firm. Administrative Science Quarterly, 37(3), 422-447.

Ingram, P. L., \& Silverman, B. S. (2002). Introduction. In P. Ingram \& B. Silverman (Eds.), The new institutionalism in strategic management (Advances in strategic management, $v .19$ ) (pp. 1-30). Amsterdam: JAI.

Ingram, P., \& Rao, H. (2004). Store Wars: The Enactment and Repeal of Anti-Chain-Store Legislation in America. American Journal of Sociology, 110, 446-487. 
James, K. S. (2011). India's demographic change: Opportunities and challenges. Science, 333(6042), 576-580.

Jia N. 2014. Are Collective and Private Political Actions Substitutes or Complements? Empirical Evidence from China's Private Sector. Strategic Management Journal 35(2): 292-315

Julian, S. D., \& Ofori - dankwa, J. C. (2013). Financial resource availability and corporate social responsibility expenditures in a sub Saharan economy: The institutional difference hypothesis. Strategic Management Journal, 34(11), 1314-1330.

Keim, G. D., \& Hillman, A. J. (2008). Political environments and business strategy: Implications for managers. Business Horizons, 51(1), 47-53.

Keim, G., \& Baysinger, B. (1988). The Efficacy of Business Political Activity: Competitive Considerations in a Principal-Agent Context. [Article]. Journal of Management, 14(2), $163-180$.

Keim, G., \& Zardkoohi, A. (1988). Looking for leverage in PAC markets: Corporate and labor contributions considered. Public Choice, 58(1), 21-34.

Khanna, T., \& Palepu, K. (1997). Why Focused Strategies May Be Wrong for Emerging Markets. [Article]. Harvard Business Review, 75(4), 41-51.

Khanna, T., \& Palepu, K. (2000). Is Group Affiliation Profitable in Emerging Markets? An Analysis of Diversified Indian Business Groups. Journal of Finance, 55(2), 867-891.

Khanna, T., \& Palepu, K. (2000). The Future of Business Groups in Emerging Markets: Long Run Evidence From Chile. Academy of Management Journal, 43(3), 268-285.

Khanna, T., Palepu, K. and Sinha, J. (2005). Strategies that Fit Emerging Markets. [Article]. Harvard Business Review, 83(6).

Khanna, T., \& Rivkin, J. W. (2001). Estimating the Performance Effects of Business Groups in Emerging Markets. Strategic Management Journal, 22(1), 45-74.

Khanna, T., \& Palepu, K. G. (2010). Winning in emerging markets: a road map for strategy and execution. Boston, Mass.: Harvard Business Press.

King, B. G., \& Pearce, N. A. (2010). The Contentiousness of Markets: Politics, Social Movements, and Institutional Change in Markets. Annual Review of Sociology, 36, 249267.

King, Andrew and Michael L. Lenox. 2000. "Industry Self-Regulation without Sanctions" the Chemical Industry's Responsible Care Program." Academy of Management Journal 43:698-716.

Kostova, T. (1999). Transnational Transfer of Strategic Organizational Practices: A Contextual Perspective. The Academy of Management Review, 24(2), 308-324.

Kostova, T., \& Roth, K. (2002). Adoption of an Organizational Practice by Subsidiaries of Multinational Corporations: Institutional and Relational Effects. The Academy of Management Journal, 45(1), 215-233. 
Kostova, T., \& Zaheer, S. (1999). Organizational Legitimacy under Conditions of Complexity: The Case of the Multinational Enterprise. The Academy of Management Review, 24(1), 64-81.

Kowalski, P., Büge, M., Sztajerowska, M., \& Egelandet, M. (2013). State-Owned Enterprises: Trade Effects and Policy Implications, OECD Trade Policy Papers, No. 147. OECD Publishing. http://dx.doi.org/10.1787/5k4869ckqk71-en

Kozhikode, R. K., \& J. T. Li. 2012. Political pluralism, public policies, and organizational choices: Banking branch expansion in India, 1948-2003. Academy of Management Journal, 55(2): 339-359.

Kraatz, M., \& Block, E. S. (2008). Organizational Implications of Institutional Pluralism. In R. Greenwood, C. Oliver, R. Suddaby \& K. Sahlin-Andersson (Eds.), The Sage Handbook of Organizational Institutionalism (pp. 243-275). London: Sage Publications Ltd.

Kriauciunas, A., \& Kale, P. (2006). The impact of socialist imprinting and search on resource change: A study of firms in Lithuania. Strategic Management Journal, 27(7), 659-679.

La Porta, R., Lopez-de-Silanes, F., Shleifer, A., \& Vishny, R. W. (1998). Law and finance. [Article]. Journal of Political Economy, 106(6), 1113-1155.

Lamertz, K., Martens, M. L., \& Pursey, P. M. A. R. H. (2003). Issue evolution: A symbolic interactionist perspective. Corporate Reputation Review, 6(1), 82-93.

Laplume, A. O., Sonpar, K., \& Litz, R. A. (2008). Stakeholder Theory: Reviewing a Theory That Moves Us. Journal of Management, 34(6), 1152-1189.

Lawrence, T. B. (1999). Institutional Strategy. Journal of Management, 25(2), 161-187.

Lawrence, T., Suddaby, R., \& Leca, B. (2011). Institutional Work: Refocusing Institutional Studies of Organization. Journal of Management Inquiry, 20(1), 52-58.

Li, H. (2001). How does new venture strategy matter in the environment-performance relationship? The Journal of High Technology Management Research, 12(2), 183-204.

Li, H., \& Atuahene-Gima, K. (2002). The Adoption of Agency Business Activity, Product Innovation, and Performance in Chinese Technology Ventures. Strategic Management Journal, 23(6), 469-490.

London, T., \& Hart, S. L. (2004). Reinventing strategies for emerging markets: beyond the transnational model. Journal of international business studies, 35(5), 350-370.

Lounsbury, M., \& Glynn, M. A. (2001). Cultural entrepreneurship: Stories, legitimacy, and the acquisition of resources. Strategic Management Journal, 22(6 7), 545-564.

Lord, M. D. (2000). Corporate Political Strategy and Legislative Decision Making: The Impact of Corporate Legislative Influence Activities Business \& Society, 39(1), 76-93.

Luo, X. \& Chung, C.-N. (2005). Keeping it all in the family: The role of particularistic relationships in business group performance during institutional transition. Administrative Science Quarterly, 50: 404-439.

Luo, X., Zhang, J., \& C. Marquis. Accounting to the Public: Internet Activism and Corporate Social Responsiveness in Emerging Markets. Working Paper 
Luo, Y. (2002). Contract, cooperation, and performance in international joint ventures. Strategic Management Journal 23.10: 903-919.

Luo, Y. (2006). Political Behavior, Social Responsibility, and Perceived Corruption: A Structuration Perspectiv. Journal of International Business Studies, 37, 6: 747-766.

Luo, Y., \& Peng, M. W. (1999). Learning to Compete in a Transition Economy: Experience, Environment, and Performance. Journal of International Business Studies, 30(2), 269295.

Luo, Y., and R. L. Tung. (2007). International expansion of emerging market enterprises: A springboard perspective. Journal of International Business Studies 38.4: 481-498.

Luthra, S., Mangaleswaran, R., \& Padhi, A. (2005). When to make India a manufacturing base. Mumbai, India: McKinsey and Company.

Lux, S., Crook, T. R., \& Woehr, D. J. (2011). Mixing Business With Politics: A Meta-Analysis of the Antecedents and Outcomes of Corporate Political Activity. Journal of Management, 37(1), 223-247.

Mahon, J. F., Heugens, P. P. M. A. R., \& Lamertz, K. (2004). Social networks and non-market strategy. Journal of Public Affairs, 4(2), 170-189.

Mair, J., and I. Marti. (2009). "Entrepreneurship in and around institutional voids: A case study from Bangladesh." Journal of business venturing 24.5: 419-435.

Mair, J., Martí, I., \& Ventresca, M. J. (2012). Building Inclusive Markets in Rural Bangladesh: How Intermediaries Work Institutional Voids. Academy of Management Journal, 55(4), 819-850.

Marquis, C., \& Battilana, J. (2009). Acting Globally but Thinking Locally? The Influence of Local Communities on Organizations Research in Organizational Behavior (Vol. 29, pp. 283-302).

Marquis, C., \& Qian, C. (2014). Corporate Social Responsibility Reporting in China: Symbol or Substance? Organization Science, 25(1), 127-148.

Marquis, C., Yin, L., \& Yang, D. (2013). Putting New Wine in Old Bottles: State-Mediated Globalization Processes and the Adoption of Sustainability Reporting in China. Harvard Business School working paper.

Marquis, C., Zhang, J., \& Zhou, Y. (2011). Regulatory Uncertainty and Corporate Responses to Environmental Protection in China. [Article]. California Management Review, 54(1), 3963.

McAdam, D., McCarthy, J. D., \& Zald, M. N. (1996). Introduction: Opportunities, Mobilizing Structures, and Framing Processes - Toward a Synthetic, Comparative Perspective on Social Movements. In D. McAdam, J. D. McCarthy \& M. N. Zald (Eds.), Comparative Perspectives on Social Movements (pp. 1-20). New York: Cambridge University Press.

McCarthy, J. D., \& Zald, M. N. (1977). Resource Mobilization and Social Movements: A Partial Theory. American Journal of Sociology, 82(6), 1212-1241.

Melewar, T. C., Badal, E., \& Small, J. (2006). Danone branding strategy in China. [Article]. Journal of Brand Management, 13(6), 407-417. 
Meyer, J. W., \& Rowan, B. (1977). Institutionalized Organizations: Formal Structure as Myth and Ceremony. The American Journal of Sociology, 83(2), 340-363.

Meyer, J. W., Boli, J., Thomas, G. M., \& Ramirez, F. O. (1997). World Society and the NationState. The American Journal of Sociology, 103(1), 144-181.

Miller, R. R. (1998). Selling to newly emerging markets. Greenwood Publishing Group.

Mitchell, R. K., Agle, B. R., \& Wood, D. J. (1997). Toward a theory of stakeholder identification and salience: Defining the principle of who and what really counts. Academy of Management Review, 22(4), 853-886.

Murrell, P., \& Wang, Y. (1993). When Privatization Should Be Delayed: The Effect of Communist Legacies on Organizational and Institutional Reforms. Journal of Comparative Economics, 17(2), 385-406.

Musacchio, A., \& Lazzarini, S. G. (2014). Reinventing state capitalism: Leviathan in business, Brazil and beyond. Cambridge, MA: Harvard University Press.

Nachum, L. (2004). Geographic and Industrial Diversification of Developing Country Firms. Journal of Management Studies, 41(2), 273-294.

Nee, V. (1992). Organizational Dynamics of Market Transition: Hybrid Forms, Property rights, and Mixed Economy in China. Administrative Science Quarterly, 37(1), 1-27.

Nee, V., \& Opper, S. (2010). Political Capital in a Market Economy. Social Forces, 88(5), $2105-$ 2132.

North, D. C. (1990). Institutions, Institutional Change, and Economic Performance. Cambridge: Cambridge University Press.

North, D. C. (1991). Institutions. Journal of Economic Perspectives, 5(1), 97-112.

O'Rourke, D. (2003). Outsourcing regulation: Analyzing nongovernmental systems of labor standards and monitoring. Policy Studies Journal, 31(1), 1-29.

Okhmatovskiy, I. (2010). Performance Implications of Ties to the Government and SOEs: A Political Embeddedness Perspective. Journal of Management Studies, 47(6), 1020-1047.

Oliver, C. (1991). Strategic Responses to Institutional Processes. Academy of Management Review, 16(1), 145-179.

Oliver, C. (1997). Sustainable Competitive Advantage: Combining Institutional and ResourceBased Views. Strategic Management Journal, 18(9), 697-713.

Oliver, C., \& Holzinger, I. (2008). The Effectiveness of Strategic Political Management: A Dynamic Capabilities Framework. [Article]. Academy of Management Review, 33(2), 496-520.

Palmer, D. A., Jennings, P. D., \& Zhou, X. (1993). Late Adoption of the Multidivisional Form by Large U.S. Corporations: Institutional, Political, and Economic Accounts. Administrative Science Quarterly, 38(1), 100-131.

Peng, M. W. (2003). Institutional Transitions and Strategic Choices. The Academy of Management Review, 28(2), 275-296. 
Peng, M. W., \& Heath, P. S. (1996). The Growth of the Firm in Planned Economies in Transition: Institutions, Organizations, and Strategic Choice. The Academy of Management Review, 21(2), 492-528.

Peng, M. W., \& Luo, Y. (2000). Managerial ties and firm performance in a transition economy: The nature of a micro-macro link. Academy of Management Journal, 43(3), 486-501.

Peng, M. W., \& Zhou, J. Q. (2005). How Network Strategies and Institutional Transitions Evolve in Asia. Asia Pacific Journal of Management, 22(4), 321-336.

Peng, M. W., Wang, D. Y. L., \& Jiang, Y. (2008). An Institution-Based View of International Business Strategy: A Focus on Emerging Economies. Journal of International Business Studies, 39(5), 920-936.

Pfeffer, J., \& Salancik, G. R. (1978). The External Control of Organizations: A Resource Dependence Perspective. New York: Harper \& Row.

Podolny, J. M. (1993). A Status-Based Model of Market Competition. The American Journal of Sociology, 98(4), 829-872.

Pop-Eleches, G. (2007). Historical Legacies and Post-Communist Regime Change. Journal of Politics, 69(4), 908-926.

Puffer, S. M., \& McCarthy, D. J. (2007). Can Russia's state-managed, network capitalism be competitive?: Institutional pull versus institutional push. Journal of World Business, 42(1), 1-13.

Puffer, S. M., McCarthy, D. J., \& Boisot, M. (2010). Entrepreneurship in Russia and China: The Impact of Formal Institutional Voids. Entrepreneurship Theory and Practice, 34(3), 441 467.

Ralston, D. A., Terpstra Tong, J., Terpstra, R. H., Wang, X., \& Egri, C. (2006). Today's state owned enterprises of China: are they dying dinosaurs or dynamic dynamos?. Strategic Management Journal, 27(9), 825-843.

Ramírez, C. D., \& Eigen-Zucchi, C. (2001). Understanding the Clayton Act of 1914: An analysis of the nterest group hypothesis. [Article]. Public Choice, 106(1/2), 157-181.

Rao, H. (1998). Caveat Emptor: The Construction of Nonprofit Consumer Watchdog Organizations. The American Journal of Sociology, 103(4), 912-961.

Raynard, M., Lounsbury, M., \& Greenwood, R. (2013). Legacies of Logics: Sources of Community Variation in CSR Implementation in China. In M. Lounsbury \& E. Boxenbaum (Eds.), Research in the Sociology of Organizations: Institutional Logics in Action (pp. forthcoming). Bingley, UK: Emerald Group.

Ready, D. A., Hill, L. A., \& Conger, J. A. (2008). Winning the race for talent in emerging markets. Harvard Business Review, 86(11), 62-70.

Rodriguez, P., Siegel, D. S., Hillman, A., \& Eden, L. (2006). Three lenses on the multinational enterprise: politics, corruption, and corporate social responsibility. Journal of International Business Studies, 37(6), 733-746.

Roland, G. (2000). Transition and economics : politics, markets, and firms. Cambridge, Mass.: MIT Press. 
Schuler, D. A. (1996). Corporate Political Strategy and Foreign Competition: The Case of the Steel Industry. The Academy of Management Journal, 39(3), 720-737.

Scott, W. R. (2001). Institutions and Organizations (2nd ed.). Thousand Oaks, CA: Sage Publications.

Scott, W. R. (2005). Institutional theory: Contributing to a theoretical research program. In K. G. Smith \& M. A. Hitt (Eds.), Great Minds in Management. Oxford: Oxford University Press.

Scott, W. R. (2008). Institutions and organizations: Ideas and interests (3rd ed.). Los Angeles: Sage Publications.

Scott, W. R. (2014). Institutions and Organizations (4th ed.). Thousand Oaks, CA: Sage Publications.

Scott, W. R., \& Davis, G. F. (2006). The subject is organizations, the verb is organizing. In W. R. Scott \& G. F. Davis (Eds.), Organizations and organizing: Rational, natural, and open systems perspectives (6th ed., pp. Chapter 1). Upper Saddle River, N.J.: Pearson Prentice Hall.

Seelos, C. and Mair, J. 2007. Profitable business models and market creation in the context of deep poverty: A strategic view. Academy of Management Perspectives, 21 (4): 49-63.

Seo, M.-G., \& Creed, W. E. D. (2002). Institutional Contradictions, Praxis, and Institutional Change: A Dialectical Perspective. Academy of Management Journal, 27(2), 222-247.

Shaffer, B., Quasney, T. J., \& Grimm, C. M. (2000). Firm Level Performance Implications of Nonmarket Actions. Business \& Society, 39(2), 126-143.

Shleifer, A., \& Vishny, R. W. (1994). Politicians and Firms. The Quarterly Journal of Economics, 109(4), 995-1025.

Siegel, J. (2007). Contingent Political Capital and International Alliances: Evidence from South Korea. [Article]. Administrative Science Quarterly, 52(4), 621-666.

Sit, V. F. S., \& Liu, W. (2000). Restructuring and Spatial Change of China's Auto Industry under Institutional Reform and Globalization. Annals of the Association of American Geographers, 90(4), 653-673.

Soule, S. A., Swaminathan, A., \& Tihanyi, L. (2014). The diffusion of foreign divestment from Burma. Strategic Management Journal, 35: 1032-1052.

Spence, Michael. 2012. The Next Convergence: The Future of Growth in a Multispeed World. New York: Picador.

Sun, P., Mellahi, K., \& Thun, E. (2010). The dynamic value of MNE political embeddedness: The case of the Chinese automobile industry. Journal of International Business Studies, 41(7), 1161-1182.

Spicer, A., McDermott, G. A., \& Kogut, B. (2000). Entrepreneurship and privitization in Central Europe. Academy of Management Review, 25(3): 630-649.

Stark, D. (1996). Recombinant property in East European capitalism. American Journal of Sociology, 101(4): 993-1027. 
Tarnovskaya, V. V. (2012). Activating Stakeholders: An Approach by MNCs in Emerging Markets. In A. Hadjikhani, U. Elg \& P. Ghauri (Eds.), Business, Society and Politics (International Business and Management) (Vol. 28, pp. 45-68): Emerald Group Publishing Limited.

Thornton, P. H., Ocasio, W., \& Lounsbury, M. (2012). The institutional logics perspective: A new approach to culture, structure, and process. Oxford: Oxford University Press.

Tilcsik, András. (2010). From ritual to reality: Demography, ideology, and decoupling in a postcommunist government agency. Academy of Management Journal 53.6: 1474-1498.

Uzo, U. and Mair, J. 2014. Source and patterns of organizational defiance of formal institutions: Insights from Nollywood, the Nigerian movie industry. Strategic Entrepreneurship Journal. 8:56-74.

Waddock, S. A., \& Graves, S. B. (1997). The corporate social performance- financial performance link. Strategic Management Journal, 18(4), 303-319.

Wade, J. B., Swaminathan, A., \& Saxon, M. S. (1998). Normative and Resource Flow Consequences of Local Regulations in the American Brewing Industry, 1845-1918. Administrative Science Quarterly 43, 905-935.

Walker, E. T. \& Rea, C. M. (2014). The political mobilization of firms and industries. Annual Review of Sociology, 40(1).

Walsh, J. P. (2005). Book review essay: Taking stock of stakeholder management. Academy of Management Review, 30(2), 426-438.

Wang, D. (2014). "Essays on state-firm interaction and firms' non-market strategies." Unpublished doctoral dissertation, INSEAD, Fontainebleau, France.

Webb, J. W., Tihanyi, L., Ireland, R. D., \& Sirmon, D. G. (2009). You say illegal, I say legitimate: Entrepreneurship in the informal economy. Academy of Management Review, 34(3), 492-510.

Weidenbaum, M. L. (1980). Public policy: No longer a spectator sport for business. Journal of Business Strategy, 1(1), 46-53.

Whitley, R. (1999). Divergent capitalisms: The social structuring and change of business systems. New York: Oxford University Press.

Williamson, O. E. (2000). The New Institutional Economics: Taking Stock, Looking Ahead. Journal of Economic Literature, 38(3), 595-613.

Wright, M., Filatotchev, I., Hoskisson, R. E., \& Peng, M. W. (2005). Strategy Research in Emerging Economies: Challenging the Conventional Wisdom. [Article]. Journal of Management Studies, 42(1), 1-33.

Xu, D., \& Shenkar, O. (2002). Institutional Distance and the Multinational Enterprise. The Academy of Management Review, 27(4), 608-618.

Yoffie, D. B. (1988). How An Industry Builds Political Advantage. [Article]. Harvard Business Review, 66(3), 82-89. 
Zhang, J., \& Luo, X. (2013). Dared to Care: Organizational Vulnerability, Institutional Logics, and MNCs' Social Responsiveness in Emerging Markets. Organization Science, 24(6), 1742-1764.

Zhang, Y., G. Duysters, and S. Filippov (2012). Chinese firms entering Europe: Internationalization through acquisitions and strategic alliances. Journal of Science and Technology Policy in China 3.2: 102-123.

Zhao, M. (2012). CSR-Based Political Legitimacy Strategy: Managing the State by Doing Good in China and Russia. [Article]. Journal of Business Ethics, 111(4), 439-460.

Zhu, H. \& Chung, C.-N. (2014). Portfolios of political ties and business group strategy in emerging economies: Evidence from Taiwan. Administrative Science Quarterly, forthcoming.

Zimmerman, M. A., \& Zeitz, G. J. (2002). Beyond Survival: Achieving New Venture Growth by Building Legitimacy. The Academy of Management Review, 27(3), 414-431.

Zu, L., \& Song, L. (2009). Determinants of Managerial Values on Corporate Social Responsibility: Evidence from China. Journal of Business Ethics, 88(1), 105-117. 
Figure 1:

World GDP Trends for Advanced and Emerging Market Economies*

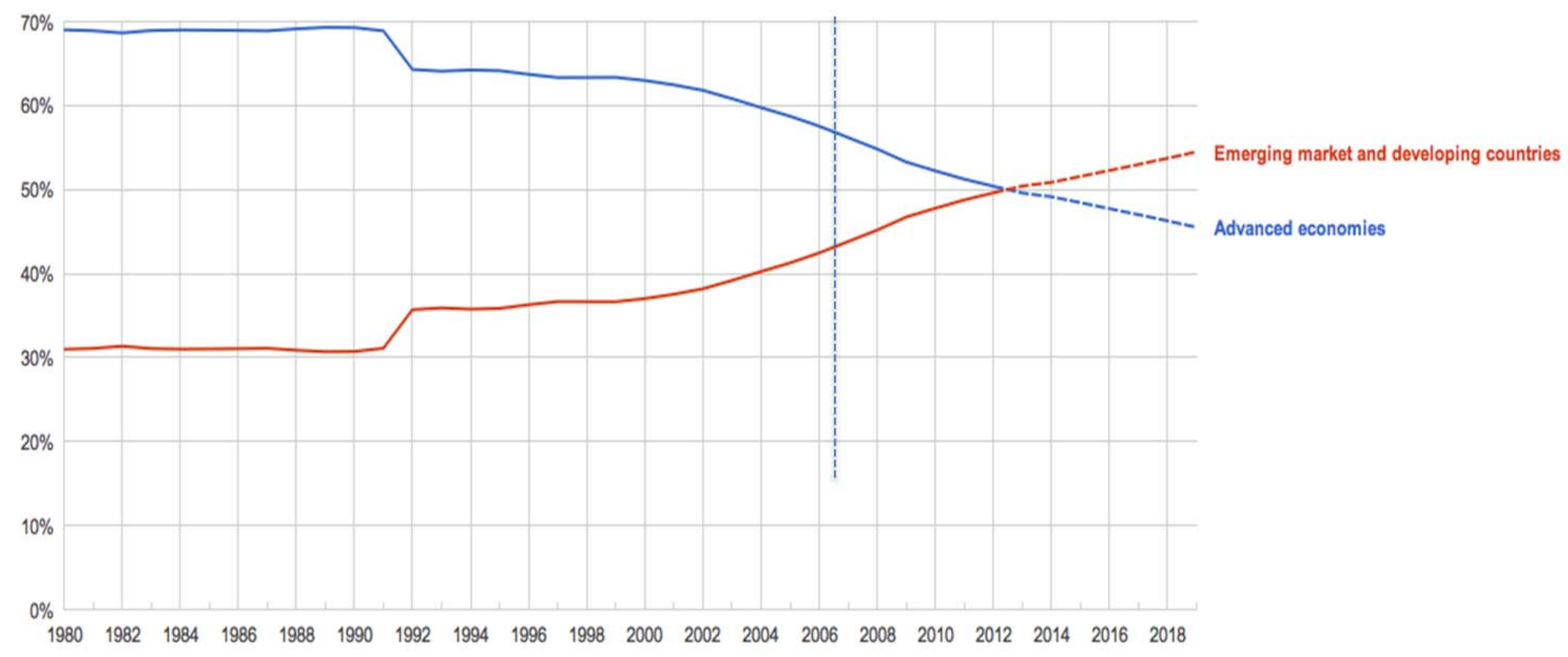

Source: International Monetary Fund, April 2014 World Economic Outlook Database

* GDP based on PPP share of world Total 
Figure 2

Average GDP Growth and Average GDP Per Capita of Major Countries of the World

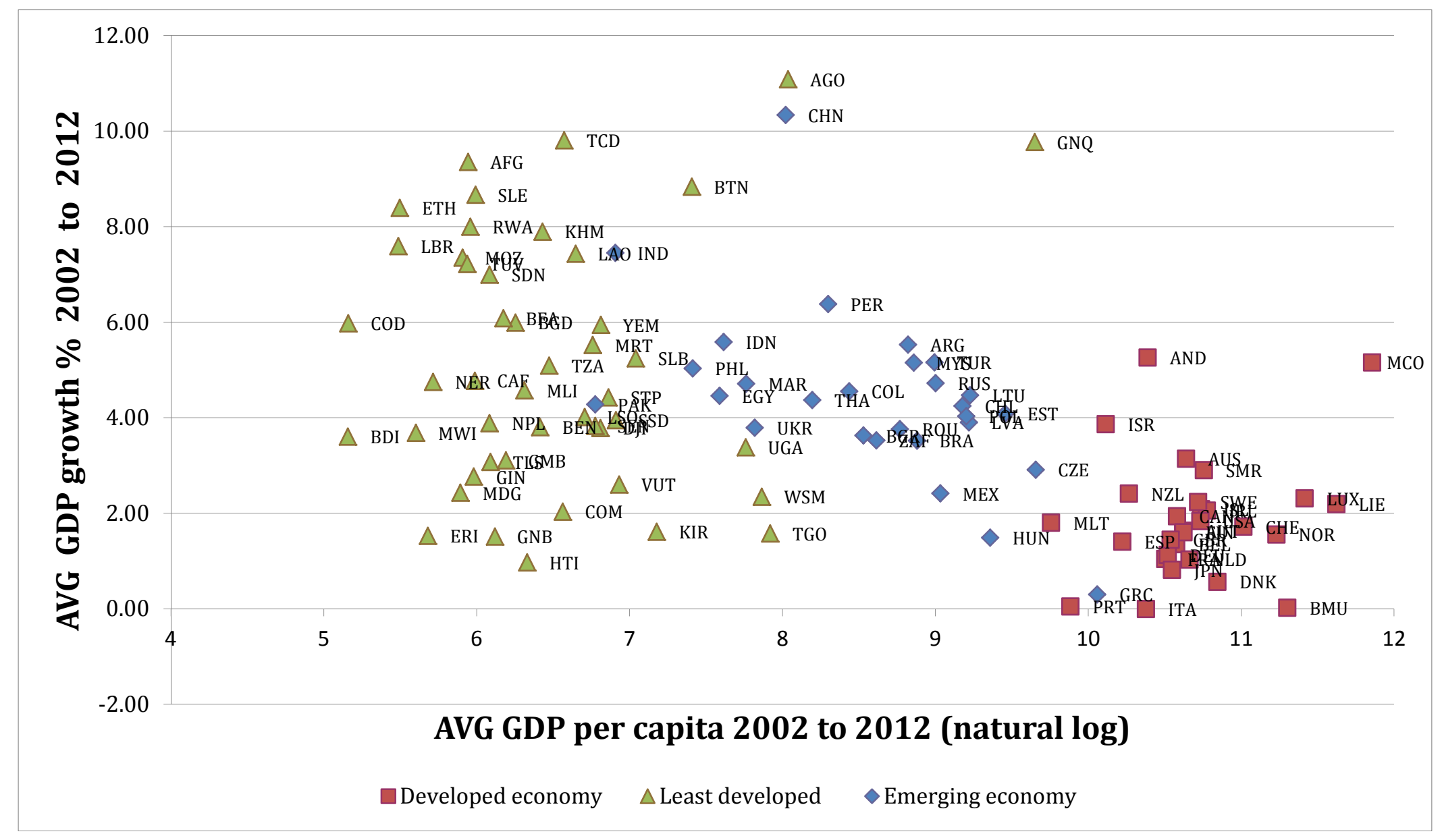


Figure 3

Emerging Markets By Political Regime Type

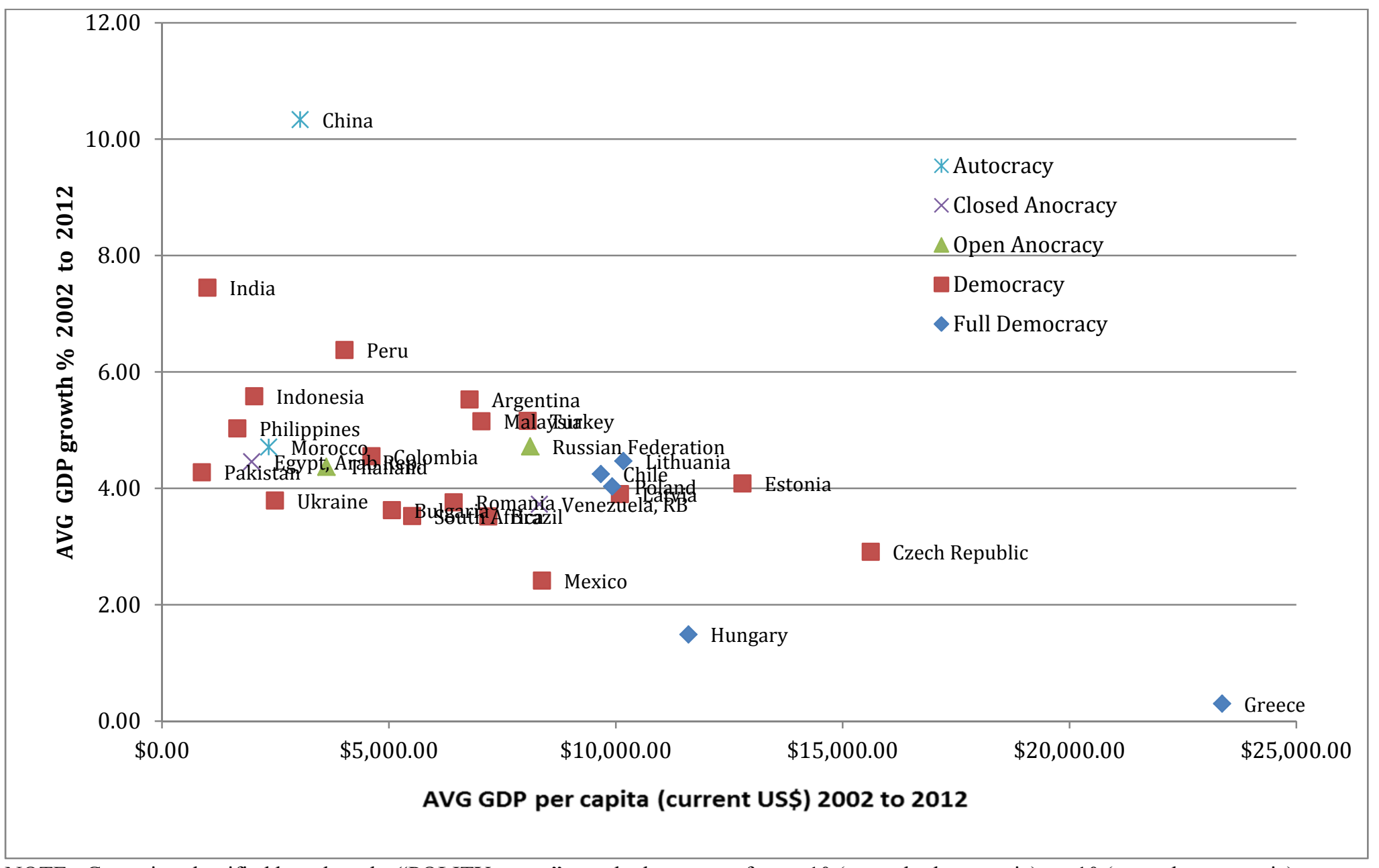

NOTE: Countries classified based on the "POLITY score," a scale that ranges from +10 (strongly democratic) to -10 (strongly autocratic). http://en.wikipedia.org/wiki/Polity data series. Autocracy $=-10$ to -6 ; Closed Anocracy = -5 to 0; Open Anocracy = 1 to 5; Democracy = 6 to 9; Full Democracy - 10. An anocracy is defined as "a regime-type where power is not vested in public institutions but spread amongst elite groups who are constantly competing with each other for power." (http://en.wikipedia.org/wiki/Anocracy) 
Table 1

Emerging Markets Identified by Major Investment Classification Sources

\begin{tabular}{|c|c|c|c|c|c|c|}
\hline Country & $\mathbf{I M F}^{\mathbf{a}}$ & FTSE $^{\mathbf{b}}$ & MSCI $^{\mathrm{c}}$ & $S \& \mathbf{P}^{d}$ & $\begin{array}{c}\text { Dow } \\
\text { Jones }\end{array}$ & Russell $^{f}$ \\
\hline Argentina & $\bullet$ & & & & $\bullet$ & \\
\hline Brazil & $\bullet$ & $\bullet$ & $\bullet$ & $\bullet$ & $\bullet$ & $\bullet$ \\
\hline Bulgaria & $\bullet$ & & & & & \\
\hline Chile & $\bullet$ & $\bullet$ & $\bullet$ & $\bullet$ & $\bullet$ & $\bullet$ \\
\hline China & $\bullet$ & $\bullet$ & $\bullet$ & $\bullet$ & $\bullet$ & $\bullet$ \\
\hline Colombia & $\bullet$ & $\bullet$ & $\bullet$ & $\bullet$ & $\bullet$ & $\bullet$ \\
\hline $\begin{array}{l}\text { Czech } \\
\text { Republic }\end{array}$ & & $\bullet$ & $\bullet$ & $\bullet$ & $\bullet$ & $\bullet$ \\
\hline Egypt & & $\bullet$ & $\bullet$ & $\bullet$ & $\bullet$ & \\
\hline Estonia & $\bullet$ & & & & & \\
\hline Greece & & & $\bullet$ & & & $\bullet$ \\
\hline Hungary & $\bullet$ & $\bullet$ & $\bullet$ & - & $\bullet$ & $\bullet$ \\
\hline India & $\bullet$ & $\bullet$ & $\bullet$ & $\bullet$ & $\bullet$ & $\bullet$ \\
\hline Indonesia & $\bullet$ & $\bullet$ & $\bullet$ & $\bullet$ & $\bullet$ & $\bullet$ \\
\hline Latvia & $\bullet$ & & & & & \\
\hline Lithuania & $\bullet$ & & & & & \\
\hline Malaysia & $\bullet$ & $\bullet$ & $\bullet$ & $\bullet$ & $\bullet$ & $\bullet$ \\
\hline Mexico & $\bullet$ & $\bullet$ & $\bullet$ & $\bullet$ & $\bullet$ & $\bullet$ \\
\hline Morocco & & $\bullet$ & & $\bullet$ & $\bullet$ & $\bullet$ \\
\hline Pakistan & $\bullet$ & $\bullet$ & & & & \\
\hline Peru & $\bullet$ & $\bullet$ & $\bullet$ & $\bullet$ & $\bullet$ & $\bullet$ \\
\hline Philippines & $\bullet$ & $\bullet$ & $\bullet$ & $\bullet$ & $\bullet$ & $\bullet$ \\
\hline Poland & $\bullet$ & $\bullet$ & $\bullet$ & $\bullet$ & $\bullet$ & $\bullet$ \\
\hline Romania & $\bullet$ & & & & & \\
\hline Russia & $\bullet$ & $\bullet$ & $\bullet$ & $\bullet$ & $\bullet$ & $\bullet$ \\
\hline South Africa & $\bullet$ & $\bullet$ & $\bullet$ & $\bullet$ & $\bullet$ & $\bullet$ \\
\hline South Korea & & & $\bullet$ & & $\bullet$ & $\bullet$ \\
\hline Taiwan & & $\bullet$ & $\bullet$ & $\bullet$ & $\bullet$ & $\bullet$ \\
\hline Thailand & $\bullet$ & $\bullet$ & $\bullet$ & $\bullet$ & $\bullet$ & $\bullet$ \\
\hline Turkey & $\bullet$ & $\bullet$ & $\bullet$ & $\bullet$ & $\bullet$ & $\bullet$ \\
\hline Ukraine & $\bullet$ & & & & & \\
\hline UAE & & $\bullet$ & & & & $\bullet$ \\
\hline Venezuela & $\bullet$ & & & & & \\
\hline
\end{tabular}

$\mathrm{a}=$ See IMF World Economic Outlook Update http://www.imf.org/external/pubs/ft/weo/2012/update/02/index.htm $\mathrm{b}=$ See FTSE Country Classification, September 2010

http://www.ftse.com/Indices/Country_Classification/Downloads/Sept\%202010/FTSE_Country_Classification_Sept_2010_Update.pdf $\mathrm{c}=$ See MSCI Emerging markets list http://www.mscibarra.com/products/indices/international_equity indices

$\mathrm{d}=$ The S\&P Global Broad Market Index, 31 December 2010, p. 2.

https://www.sp-indexdata.com/idpfiles/citigroup/prc/active/factsheets/Factsheet_SP_Global_BMI.pdf

$\mathrm{e}=$ See Dow Jones Indexes Country Classification System

http://www.djindexes.com/mdsidx/downloads/brochure_info/Dow_Jones_Indexes_Country_Classification_System.pdf

$\mathrm{f}=$ See Russell Global Indexes - Construction and Methodology

http://www.russell.com/documents/indexes/construction-methodology-global-indexes.pdf 
Table 2

Key Differences Between Developed and Emerging Markets on Economic and Institutional Dimensions

\begin{tabular}{|c|c|c|c|}
\hline & Developed Markets & Emerging Markets & $\begin{array}{l}\text { Implications for } \\
\text { Operating in EMs }\end{array}$ \\
\hline $\begin{array}{l}\text { Economic } \\
\text { Conditions }\end{array}$ & $\begin{array}{l}\text { - Developed capital markets } \\
\text { with moderate to high } \\
\text { levels of liquidity } \\
\text { - 'Meaningful' regulatory } \\
\text { bodies } \\
\text { - Large market } \\
\text { capitalization } \\
\text { - High levels of per capita } \\
\text { income } \\
\text { - Dominance of industrial } \\
\text { and service sector } \\
\text { - Large-scale production of } \\
\text { commodities } \\
\text { - Minimal trade barriers } \\
\text { - Low GDP growth rates }\end{array}$ & $\begin{array}{l}\text { - Marginally developed capital } \\
\text { markets with low levels of } \\
\text { market liquidity } \\
\text { - Low levels of per capita } \\
\text { income and high income } \\
\text { inequality } \\
\text { - Rapid economic growth and } \\
\text { development } \\
\text { - Volatility in financial capital } \\
\text { inflows } \\
\text { - High levels of inflation } \\
\text { - Modernization of } \\
\text { infrastructure as the economy } \\
\text { moves from a dependence on } \\
\text { agriculture to manufacturing } \\
\text { - Dominance of manufacturing } \\
\text { and labor-intensive industries } \\
\text { - Decreasing trade barriers } \\
\text { - High GDP growth rates }\end{array}$ & $\begin{array}{l}\text { - Increased transaction } \\
\text { costs } \\
\text { - Market vulnerabilities to } \\
\text { large macroeconomic and } \\
\text { political instabilities } \\
\text { - Rampant opportunistic } \\
\text { behavior, bribery, and } \\
\text { corruption } \\
\text { - High potential for growth } \\
\text { and investment } \\
\text { - Growing consumer base } \\
\text { with discretionary income }\end{array}$ \\
\hline $\begin{array}{l}\text { Institutional } \\
\text { Conditions } \\
\text { (political, } \\
\text { legal, socio- } \\
\text { cultural, } \\
\text { technological) }\end{array}$ & $\begin{array}{l}\text { - Formal regulatory } \\
\text { infrastructure in place (e.g. } \\
\text { market regulation, } \\
\text { corporate governance, } \\
\text { transparency and } \\
\text { accounting standards) } \\
\text { - Moderate to high standard } \\
\text { of living } \\
\text { - Moderate to high Human } \\
\text { Development Index (HDI) } \\
\text { levels (education, literacy, } \\
\text { and health) } \\
\text { - Advanced technological } \\
\text { and commercial } \\
\text { infrastructure } \\
\text { - High degree of political } \\
\text { freedom } \\
\text { - Little government } \\
\text { intervention in business }\end{array}$ & $\begin{array}{l}\text { - Non-transparent political and } \\
\text { regulatory environment } \\
\text { - Young population and } \\
\text { expanding working } \\
\text { population } \\
\text { - Increasing urbanization } \\
\text { - Burgeoning middle class } \\
\text { - Growing demand for } \\
\text { consumer goods and } \\
\text { infrastructure development } \\
\text { - Prevalence of state-owned } \\
\text { firms } \\
\text { - Low to moderate degree of } \\
\text { political freedom } \\
\text { - Moderate to high levels of } \\
\text { government intervention in } \\
\text { business }\end{array}$ & $\begin{array}{l}\text { - Constraints on types of } \\
\text { activities organizations } \\
\text { can engage in } \\
\text { - Limited property rights } \\
\text { and intellectual property } \\
\text { protection } \\
\text { - Underdeveloped physical } \\
\text { and commercial } \\
\text { infrastructure } \\
\text { - Lack of availability of } \\
\text { skilled labor and/or } \\
\text { expertise } \\
\text { - Ideologically-fuelled } \\
\text { political and social unrest } \\
\text { - Risk of government } \\
\text { intervention and } \\
\text { expropriation } \\
\text { - Importance of informal } \\
\text { networks and } \\
\text { relationships }\end{array}$ \\
\hline
\end{tabular}


Table 3

Types of Institutional Strategies in Emerging Markets

\begin{tabular}{|c|c|}
\hline $\begin{array}{l}\text { Institutional Strategy Types } \\
\text { and Definitions }\end{array}$ & Importance in Emerging Markets \\
\hline $\begin{array}{l}\text { Relational Strategies: The } \\
\text { actions and activities taken to } \\
\text { interact with and strategically } \\
\text { manage important referent } \\
\text { audiences, including political } \\
\text { bodies and key stakeholder groups. }\end{array}$ & $\begin{array}{l}\text { - Cultivate interpersonal networks and social capital as } \\
\text { 'substitutes' for weak market structures and } \\
\text { underdeveloped regulatory and legal infrastructures } \\
\text { - Engage in political strategies focused on furthering } \\
\text { organizational self-interests instead of directly influencing } \\
\text { public policy - e.g. government subsidies and tax } \\
\text { exemptions, access to key factors of production and } \\
\text { valuable natural resources, etc. } \\
\text { - Leverage informal connections and relationships to reduce } \\
\text { uncertainty, protect private property, and regulate social } \\
\text { behavior }\end{array}$ \\
\hline $\begin{array}{l}\text { Infrastructure-Building } \\
\text { Strategies: The actions and } \\
\text { activities taken to address } \\
\text { marginally developed markets, and } \\
\text { underdeveloped social, } \\
\text { technological, and physical } \\
\text { infrastructures. }\end{array}$ & $\begin{array}{l}\text { Engage in collective organizing to pursue and promote } \\
\text { infrastructure development } \\
\text { - Develop informal mechanisms and standardization } \\
\text { strategies for addressing 'institutional voids' } \\
\text { - Develop or promote global standards to foster a common } \\
\text { language and understanding of business practices and } \\
\text { outcomes }\end{array}$ \\
\hline $\begin{array}{l}\text { Socio-cultural Bridging } \\
\text { Strategies: The actions and } \\
\text { activities taken to address the } \\
\text { socio-cultural and demographic } \\
\text { issues/challenges, which shape the } \\
\text { competitive environment. }\end{array}$ & $\begin{array}{l}\text { - Develop knowledge and experience of local conditions and } \\
\text { features - e.g. partnering with local firms, hiring local } \\
\text { senior managers and consultants, investing in field } \\
\text { investigations, learning from local competitors, and } \\
\text { building local talent and capacity } \\
\text { - Recognize that the legacies of past political regimes may } \\
\text { continue to shape the business environment, particularly in } \\
\text { transition economies - e.g. excess physical and human } \\
\text { resources, strong societal expectations for organizations act } \\
\text { as 'mini welfare states', etc. }\end{array}$ \\
\hline
\end{tabular}

